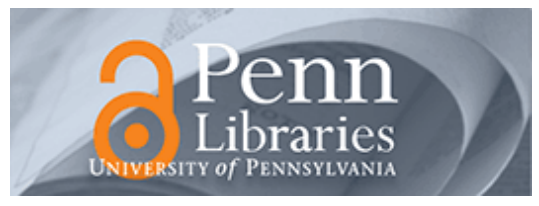

University of Pennsylvania

ScholarlyCommons

Management Papers

Wharton Faculty Research

5-2017

\title{
Growing Apart: The Changing Firm-Size Wage Premium and Its Inequality Consequences
}

\author{
Adam Cobb \\ University of Pennsylvania \\ Ken-Hou Lin \\ University of Texas
}

Follow this and additional works at: https://repository.upenn.edu/mgmt_papers

Part of the Management Sciences and Quantitative Methods Commons

\section{Recommended Citation}

Cobb, A., \& Lin, K. (2017). Growing Apart: The Changing Firm-Size Wage Premium and Its Inequality Consequences. Organization Science, 28 (3), 429-446. http://dx.doi.org/10.1287/orsc.2017.1125

This paper is posted at ScholarlyCommons. https://repository.upenn.edu/mgmt_papers/187

For more information, please contact repository@pobox.upenn.edu. 


\title{
Growing Apart: The Changing Firm-Size Wage Premium and Its Inequality Consequences
}

\begin{abstract}
Wage inequality in the United States has risen dramatically over the past few decades, prompting scholars to develop a number of theoretical accounts for the upward trend. This study argues that large firms have been a prominent labor-market institution that mitigates inequality. By compensating their lowand middle-wage employees with a greater premium than their higher-wage counterparts, large U.S. firms reduced overall wage dispersion. Yet, broader changes to employment relations associated with the demise of internal labor markets and the emergence of alternative employment arrangements have undermined large firms' role as an equalizing institution. Using data from the Current Population Survey and the Survey of Income and Program Participation, we find that in 1989, although all private-sector workers benefited from a firm-size wage premium, the premium was significantly higher for individuals at the lower end and middle of the wage distribution compared to those at the higher end. Between 1989 and 2014, the average firm-size wage premium declined markedly. The decline, however, was exclusive to those at the lower end and middle of the wage distribution, while there was no change for those at the higher end. As such, the uneven declines in the premium across the wage spectrum could account for about $20 \%$ of rising wage inequality during this period, suggesting that firms are of great importance to the study of rising inequality.
\end{abstract}

\section{Keywords}

firm-size wage premium, inequality, internal labor market, employment relationship

\section{Disciplines}

Management Sciences and Quantitative Methods 


\title{
Growing Apart: The Changing Firm-Size Wage Effect and Its Inequality Consequences
}

\author{
J. Adam Cobb* \\ Assistant Professor of Management \\ The Wharton School \\ University of Pennsylvania \\ Ken-Hou Lin \\ Assistant Professor \\ Department of Sociology \\ University of Texas \\ Paige Gabriel \\ $\mathrm{PhD}$ Candidate \\ Department of Sociology \\ University of Texas
}

Acknowledgements: The authors thank Alan Benson, Matthew Bidwell, Peter Cappelli, JR Keller, David Pedulla and participants at the Labor and Employment Relations Association Conference for thoughtful comments on earlier versions of the paper.

*The first two authors contributed equally and are listed in alphabetical order 


\begin{abstract}
Wage inequality in the United States has risen dramatically over the past several decades, prompting scholars to develop a number of theoretical accounts for the upward trend. This study takes an organizational approach to examine how changes in the firm-size wage effect (FSWE)a phenomenon whereby otherwise similar workers earn more when employed by large firmshave affected the wage distribution in the U.S labor market. Using data from the Current Population Survey and Survey of Income and Program Participation, our findings reveal that in 1987, although all workers benefited from a firm-size wage premium, the premium was significantly higher for individuals at the bottom (e.g., 10th and 25th percentiles) and middle of the wage distribution (e.g., 50th percentile) compared to those at the top (90th percentile). Between 1987 and 2014, however, whereas the average FSWE declined markedly, the decline was exclusive to those at the bottom and middle of the wage distribution while there was no change for those at the top. As such, the uneven declines in the FSWE across the wage distribution explain between 20 and 30 percent of rising wage inequality during this period, suggesting firms are of great importance to the study of rising inequality.
\end{abstract}


Over the past several decades in the United States, one trend that has garnered much debate is the dramatic rise in wage inequality. Driven in large part by a widening wage distribution, between 1976 and 2014, income inequality, as measured by the Gini coefficient, rose nearly 21 percent. ${ }^{1}$ While scholars have primarily used market (e.g., globalization, skill-biased technological change) or institutional (e.g., unionization, public policy) explanations to account for the rise (see Morris and Western 1999), recent studies have begun to investigate whether and how organizations affect the distribution of earnings in the broader labor market (e.g., Avent-Holt and TomaskovicDevey 2014; Barth et al. 2014; Song et al. 2015; Sørensen and Sorenson 2007). Organizations are a likely important driver of inequality because they provide unequal access to remuneration and rewards (Abowd and Kramarz 1999; Baron 1984; DiNardo, Fortin, and Lemieux 1996). Hence, explanations for rising inequality that consider organizations' compensation practices and how those practices change over time hold considerable potential.

One area of interest among stratification scholars has been to examine how workers' economic rewards vary by firm size. This focus on firm size is due, in part, to the well-documented empirical regularity that otherwise identical workers earn more when employed by large firmsa phenomenon referred to as the firm-size wage effect (FSWE) (Oi and Idson 1999). One approach to the study of firms and wage inequality has been to examine changes in proportion of workers employed by large firms and its inequality consequence. For example, Davis and Cobb (2010) chronicled a marked decline in the proportion of U.S. workers employed in the largest firms between 1950 and 2010 and found that this decline, at the aggregate level, was related to rising wage inequality in the U.S. during this period. While enlightening, this research does not examine

\footnotetext{
${ }^{1}$ https://www.census.gov/hhes/www/income/data/historical/inequality/Table\%20IE-1.pdf
} 
the wage outcomes of firm size directly, and thus implicitly assumes that the wage-setting practices of large firms have remained relatively constant over time.

To help address this concern, this study examines directly how the allocation of rewards inside large firms depends on one's location in the wage distribution and whether this allocation has changed over time. Though prior research has yet to examine this question directly, it has offered some important clues. For example, research has found that the FSWE is greater for lesseducated versus higher-educated workers (e.g., Even and Macpherson 2012; Hollister 2004), suggesting that large firms compress wages, and more generally that firm-size wage premiums vary across the wage distribution. Moreover, research has chronicled a steady decline in the FSWE (e.g., Hollister 2004), suggesting that the benefits of large-firm employment may be decreasing. Taken together, these developments have potential implications for rising levels of wage inequality in the United States. Yet, to date, the distributional consequences of the FSWE have been largely unexplored.

The primary purposes of this study are thus twofold. First, we examine whether there is cross-sectional variance in the FSWE across the wage distribution. It is commonly speculated that in order to maintain perceptions of equity inside the firm, large employers compress workers' wages by paying their low- and mid-wage workers a greater wage premium than higher-wage workers (e.g., Cappelli 2001; Davis and Cobb 2010; Nickerson and Zenger 2008). As such, we examine whether the firm-size wage premium is greater for low- and mid-wage workers in comparison to their higher-wage counterparts.

Second and relatedly, we examine whether the propensity for large firms to compress wages has changed over time. More specifically, we analyze whether the decline of the FSWE varied across the wage distribution. Drawing insights from research on the FSWE (e.g., Kalleberg 
and Van Buren 1994) and research on changing employment relations (e.g., Cappelli 1999), we contend that the mechanisms that once motivated large firms to compress wages have been undermined by emerging employment practices. Thus, much of the decline in the average FSWE is likely concentrated among lower- and middle-wage workers. In doing so, we illuminate the inequality consequence of the FSWE by accounting for how the cross-sectional and temporal changes in the FSWE have jointly affected the overall U.S. wage distribution.

Using data collected from the Current Population Survey (CPS) and the Survey of Income and Program Participation (SIPP), we examine the variation of the firm-size wage premium across the wage distribution and over time with recentered influence function (RIF) regressions. Our findings reveal that, although all workers benefited from a firm-size wage premium, the premium was significantly higher for individuals at the bottom (e.g., 10th and 25th percentiles) and middle of the wage distribution (e.g., 50th percentile) compared to those at the top (e.g., 90th percentile). Between 1987 and 2014, however, while the average FSWE declined considerably, the decline occurred most sharply among those at the bottom and middle of the wage distribution. Conversely, the FSWE has remained unchanged for those at the top of the wage distribution employed by firms with 500-999 workers and increased modestly for comparable workers employed by firms with 1,000 or more workers. By 2014 the FSWE was similar for all workers irrespective of earnings level. The findings are robust against compositional differences in human capital, worker tenure, union status, industrial sector of employment, and other supply-side characteristics. We also show that the decline in the FSWE for individuals in the lower and middle portion of the wage distribution helps account for 20-30 percent of rising wage inequality during this period.

The paper is organized as follows: we begin with an overview of the literature on the FSWE, focusing on prior explanations for its existence. We then discuss our arguments for why 
the FSWE is higher for lower- and middle-wage workers, why we expect declines in the FSWE to be greater for these workers, and why we expect these declines to be related to rising wage inequality in the United States. We conclude with a discussion of implications for theory and empirical research on both the FSWE and wage inequality.

\section{THE FIRM-SIZE WAGE EFFECT}

\section{Summary}

A long tradition of sociological research has been interested in the effects of firm size on various outcomes. For instance, firm size is positively correlated with organizational complexity, formalization, vertical differentiation, and diversification (Blau and Schoenherr 1971; Child 1972; Kalleberg and Van Buren 1994; Kimberly 1976), and has been found to have a profound effect on the organization of work (see Baron and Bielby 1984). In fact, firm size is the organizational characteristic most frequently used in studies of stratification (Kalleberg and Van Buren 1996; Villemez and Bridges 1988). The attention to firm size in studies of stratification has occurred, in part, because research on employment and compensation has consistently found that otherwise identical workers earn more when working for large firms. Empirical studies reveal, for example, that firms with 500 or more workers pay wages that are 30- to 50-percent higher than those of firms with fewer than 25 workers (for a review, see Oi and Idson 1999). Studies dating back to the turn of the 20th century have documented this empirical regularity in the United States (e.g., Moore 1911), and scholars have found evidence of the FSWE in diverse countries such as Canada (Lluis 2009), South Korea (Sun and Kim 2014), Spain (El-Attar and Lopez-Bazo n.d.), and Sweden (Fox 2009).

A number of theories for the existence of the FSWE have been proposed, and much research on the topic has sought to test these various explanations. A common theme among these 
accounts is the idea that the FSWE is a proxy for a factor (or factors) that are typically unobserved with existing data (Hollister 2004). The more prominent theories, which we briefly summarize below, are based upon size-related differences in human capital, monitoring costs, monopoly power, union effects, and organizational structures.

Human capital explanations for the FSWE contend that firm-size wage premiums are due to the ability and/or desire of large firms to attract more productive workers (Garicano and RossiHansberg 2006). Screening and monitoring costs may increase as firms grow (Evans and Leighton 1989; Garen 1985; Oi 1983); thus large firms pay wage premiums both to attract higher-quality workers and to discourage workers from shirking. Indeed, studies have found that between onethird and one-half of the gross differences in wages between large and small firms can be explained by human capital characteristics (e.g., Criscuolo 2000; Troske 1999).

Monopoly power explanations contend that larger firms have more financial resources due to their ability to generate rents through their monopolistic position in product markets (Brown, Hamilton, and Medoff 1990; Dalton and Ford 1977; Mellow 1982). By sharing in these rents with their workforce, firms can engender a more cooperative work environment (Pedace 2010). Employees may also use the firm's product market power to bargain for higher wages for themselves (Nickell, Vainiomaki, and Wadhwani 1994). The union effects hypothesis suggests the FSWE may be due to higher rates of unionization in large firms and because large firms use wage premiums to stave off labor-organizing attempts (Hodson and Kaufman 1982). Prior research, however, has found mixed evidence on whether monopoly power and unionization effects are responsible for the FSWE (Brown and Medoff 1989; Even and Macpherson 2012).

Other scholars have argued that the FSWE is due to differences in the types of employment practices and organizational structures used by large firms (e.g., Hollister 2004). Previous research 
has found firm size to be strongly correlated with organizational practices such as formalization, training, and internal labor markets (Aldrich and Marsden 1988; Kalleberg and Van Buren 1996). These practices require workers to invest in firm-specific skills, and thus premium wages may accompany such practices as a means to incentivize workers to make these investments and to reduce worker turnover. Thus, the FSWE may simply be a proxy for the effect of these practices on worker wages.

More recently, several studies have documented a steady decline in the FSWE in the United States. For example, Hollister (2004) found that the FSWE declined by about one-third between 1988 and 2003, and that while human capital characteristics can explain some portion of the FSWE in the cross-section, they do not explain the decline over time. Shifts in organizational structures, particularly the decline in internal labor markets (ILMs), however, do help explain the decline. Even and MacPherson (2012) found a similar decline (38 percent) in the FSWE between 1988 and 2007. In contrast, however, the authors found that a significant portion of the decline could be explained by declines in unionization and a convergence in the returns to worker characteristics at large and small firms.

While not exhaustive, the literature review above provides a general sense of the various explanations for why the FSWE exists and why it has decreased. Though understanding and documenting the FSWE and its decline is an important area of inquiry, this study takes a different approach, focusing instead on whether changes in the FSWE have occurred differentially throughout the wage distribution. Prior research has found, for example, that the union wage premium (Fortin, Lemieux, and Firpo 2011) and the financial wage premium (Lin 2015) vary across the earnings distribution. If it is the case that the firm-size wage premium is associated with the level of earnings, an exclusive focus on the general decline would overlook its variation among 
workers. Moreover, an emphasis on the average would obscure how the firm-size wage premium may shape overall wage inequality in the United States.

Our core argument is that the emerging employment practices documented in prior studies (e.g., Cappelli 1999; Davis 2009a; Lin 2013) have disproportionately lowered the wage premium received by low- and mid-wage workers in large firms by setting their pay closer to market rates (see also Dencker and Fang 2016). ${ }^{2}$ One result of these changes is that they will negatively affect the firm-size wage premiums received by these workers relative to higher-wage ones. In the sections below, we first consider the relation between firm size and wage allocations and why, much like labor unions, firms could play a critical role in moderating wage disparity. This is followed by a discussion on the recent trends in employment practices and corporate organization more broadly that may disproportionately affect the ability of low- and mid-wage workers to earn a greater firm-size wage premium. We then consider how the differential changes in the FSWE is a proximal mechanism that may have affected overall wage inequality in the United States during the period of observation.

\section{The Firm-Size Wage Effect across the Wage Distribution}

Human-capital-based theories emphasize that earnings are primarily a product of an individual's productive capacity (e.g., Becker 1964). As such, individuals with identical skills

\footnotetext{
${ }^{2}$ Throughout, we make reference to pay being determined by worker productivity and market dynamics. We are agnostic, however, regarding whether wages are a true reflection of worker productivity and market factors or an outcome of social processes that influence perceptions of worker value (see Avent-Holt and Tomaskovic-Devey 2014). Here, we are concerned only with the going wage in the labor market rather than what factors determine that wage.
} 
should obtain relatively equivalent earnings regardless of the job they are in. In practice, however, wages are tied to jobs rather than workers (Granovetter 1981), and once we allow features of a job to influence wage outcomes, how firms match workers to positions and how they reward workers for their labor become important determinants of how labor income is distributed in a society (Sørensen and Sorenson 2007).

Assigning wages to jobs is a hallmark of ILMs, sets of practices commonly used by large corporate employers to determine how workers are allocated to jobs and how they are rewarded for their labor (Doeringer and Piore 1971). In the aftermath of World War II, ILMs emerged in most large U.S. firms as a consequence of fierce negotiations between labor unions and management over the terms of employment. In an attempt to curtail managerial discretion over compensation decisions and to reduce opportunities for discrimination, favoritism, and nepotism, collective bargaining agreements helped institutionalize bureaucratic routines for allocating workers to jobs and setting their pay (Lichtenstein 2002). These systems were also adopted by nonunionized workplaces in an effort to forestall unionization (Jacoby 1985) and to help comply with governmental regulations around equal opportunity (Dobbin et al. 1993). A defining characteristic of wage-setting schemes in ILMs was that wages were almost exclusively based on the job an individual held rather than the characteristics of that individual (Doeringer and Piore 1971; Granovetter 1981).

Although jobs that require greater levels of competencies and are more highly valued by the firm receive greater pay, historically compensation systems inside ILMs were developed to create a sense of internal pay equity (Dulebohn and Werling 2007; Sanchez and Levine 2012). That is, by assigning wages to jobs and establishing criteria by which jobs are compared, employers hope to mitigate perceptions of inequity in how wages throughout the hierarchy are set 
(Osterman 1999; Pfeffer and Davis-Blake 1992). To create and maintain perceptions of equity, firms are likely to compress wages both horizontally—whereby workers in the same job receive roughly equivalent pay, and vertically — whereby the distribution of pay throughout the hierarchy is compressed relative to an expected marginal product schedule (Nickerson and Zenger 2008).

To compress wages vertically, large firms can raise the wage floor for lower-wage workers and/or pay higher-wage workers below their marginal product. Yet, there are reasons to expect that vertical compression may have been more typically accomplished by raising the wage floor for low- and mid-wage workers. For example, paying higher-skilled workers below market wages may make it difficult for large firms to attract and retain these employees (Zenger 1994). To the extent that large firms rely on the presence of higher-skilled workers to transform resources into output, firms may be reluctant to vertically compress wages by paying them below market rates. Furthermore, offering a wage premium - that is, wages above what would be realized in a perfectly competitive market (Sørensen 2000; Tomaskovic-Devey and Lin 2011) — can be used as a means to ensure worker loyalty, reduce shirking, and/or stave off unionization attempts (Yellen 1984). Because these concerns may be stronger among lower- and middle-wage workers (e.g., production workers), we might expect firms to offer a larger premium to those at the bottom and middle of the wage distribution as opposed to those at the top of it.

Prior evidence suggests that, historically, premium wages were more common for production jobs than for professional jobs (Cappelli and Chauvin 1991; Raff and Summers 1987). Similarly, Jacoby (1997) found that while Kodak historically paid its workers premium wages on average, the firm paid its production employees even more in relative terms than it paid nonproduction jobs in order to exceed the typical wages of unionized workers. There is also evidence that the FSWE was higher for those with lower levels of education (Even and 
Macpherson 2012; Hollister 2004) and that ILMs provided higher wage premiums for lowerskilled workers than higher-skilled ones (Groshen and Levine 1998), suggesting also that lowerand middle-wage employees benefited disproportionately from large-firm employment. Taken together, we expect that in a desire to maintain perceptions of equity, large firms will be particularly apt to vertically compress wages by raising the wage floor for lower- and middle-wage workers, such that the FSWE will be higher for lower- and middle-wage workers than their higherwage counterparts. Stated formally, we expect the following:

Hypothesis 1: The firm-size wage effect is larger for low-wage and mid-wage workers than for high-wage workers.

\section{Changing Firm-Size Wage Effect over Time}

The discussion above contends that large firms are likely to compress the wage distribution by paying higher wage premiums to low- and middle-wage workers. Yet, many large U.S. corporations now compete in progressively more uncertain environments as advances in information and communication technologies, globalization, and deregulation have raised product market competition and shortened product life cycles (Osterman et al. 2001). Financial market pressures have also increased, placing even greater pressure on firms to maintain a shorter-term focus on market performance (Davis 2009b; Dobbin and Jung 2010; Lin 2013; Lin and Tomaskovic-Devey 2013; Sørensen 2000). The heightened uncertainty these changes place on firms has motivated many large U.S. companies to shift some of that uncertainty onto their workers (Cobb 2015; Hacker 2008). In so doing, many large U.S. corporate employers have fundamentally restructured their employment relations by altering the way they remunerate individuals for their labor and where they place firm boundaries (Cobb 2016; Dencker and Fang 2016; Jacoby 2005). The end result of these transformations, we contend, has disproportionately affected those at the 
bottom and middle portions of the wage distribution. In this section we highlight these interwoven changes and discuss their impacts on the FSWE for workers at different points in the wage distribution.

First, research has documented a steady decline in prevalence of ILMs over the past four decades (e.g., Bidwell et al. 2013; Piore 2002). One of the main pieces of evidence to support this claim is the decline in the returns to tenure with same employer during the 1980s and 1990s (Cappelli 2001; Chauvin 1992; DiPrete, Goux, and Maurin 2002). Other indications of the declining ILMs are large firms' increased use of external hiring (Bidwell 2011; Crispin and Mehler 2013), lower tenure rates (Bidwell 2013), and reductions in firm-sponsored training (Knoke and Kalleberg 1994).

As ILMs have declined, in their place has emerged a set of external market-based employment practices that do not rely on bureaucratic routines to determine remuneration and promote internal equity. Rather, in a market-oriented wage-setting system, wages are more likely to be based on workers' relative performance, skills, and credentials, as well as on the broader market forces of supply and demand (Cappelli et al. 1997). Because individual variations in performance can be significant (Bandiera, Barankay, and Rasul 2007; Schmidt and Hunter 1981), wage-setting systems that reward workers based on their productivity increase the wage gap between more- and less-productive workers.

One such system designed to closely link productivity to pay is pay-for-performance schemes, which became increasingly widespread after the 1982 recession as U.S. firms faced pressures to improve worker efficiency; between 80 to 90 percent of U.S. corporations implemented such plans in the succeeding decades (Heneman and Werner 2005). External marketbased compensation schemes set worker wages much closer to rates found in the broader market 
and increase the wage disjuncture within jobs as well as across hierarchical levels. As such, external market-based compensation systems are "rent destroying" for many low- and mid-wage workers as they reduce workers' ability to earn a wage premium for their labor (Dencker and Fang 2016; Sørensen 2000). In contrast, evidence has found that firms have become increasingly more likely to use compensation systems that reward higher-skilled, higher-ranking workers for the performance of a division or firm, which has greatly increased the wages of these workers (Bell and Van Rennen 2014; Lemieux, MacLeod, and Parent 2009; Schweiker and Groß 2016).

In addition to the demise of ILMs, other practices have helped to reshape firm boundaries in ways that likely disproportionately lower the economic rewards for lower- and middle-wage workers. A prime example of such changes is the use of outsourcing and other nonstandard work arrangements (Cappelli and Keller 2013; Davis-Blake and Broschak 2009). Beginning in the early 1990s, many large firms, particularly those involved in the production of goods, sent their manufacturing overseas, and many back-office services found new homes at home and abroad. Spurred by new theory emphasizing the importance of firms to focus on their "core competence" (Lepak and Snell 1999), as well as financial markets rewarding firms for generating profits while harboring fewer physical assets (Lin 2013; Lowenstein 1997), externalizing their workforce through the use of contract work, temporary work, and outsourcing emerged as the au courant approach for firms attempting to lower labor costs and maintain flexibility in uncertain product market environments (Cappelli and Keller 2013; Matusik and Hill 1998).

The rise of outsourcing and other nonstandard work arrangements has had a particularly deleterious effect on lower- and middle-wage employees. Outsourcing limits the amount of withinfirm heterogeneity of abilities and rewards, allowing firms to disperse wages without triggering perceptions of inequity among high- and low-skilled workers (Rawley and Simcoe 2010). Rather 
than administrative rules and procedures determining the pay, once outsourced, the external market for a job becomes a reference point through which wages are set (Kochan and Riordan 2016). Supporting this view, Dube and Kaplan (2010) found that outsourced janitors and security guards earned routinely less than their in-house counterparts, due primarily to the fact that firms replaced relatively mid- to high-paying jobs with lower-paying jobs. Similar trends have been found in studies on subcontracting in call centers (Batt, Colvin, and Keefe 2002), hotels (Hertz 2010), and school cafeterias (McCain 2009). Meanwhile, many high-skilled contract workers benefit from outsourcing as they frequently earn higher wages than their in-house counterparts (Houseman, Kalleberg, and Erickcek 2003; Kunda, Barley, and Evans 2002).

What these results therefore suggest is that once a job is separated from a firm's ILM its wages will be set more closely to the going market rate (Cappelli 2001). Moreover, outsourcing, and the threat of outsourcing, may also depress the wages of nonoutsourced workers by reducing their bargaining power (Bernhardt et al. 2016). The implication, then, is that lower- and middlewage workers will be most negatively affected by outsourcing and the use of other nonstandard work arrangements. While firms of all sizes may utilize these various arrangements, evidence suggests outsourcing and nonstandard work practices are used more prevalently by larger firms (Cappelli and Keller 2013). Hence the probability of jobs being outsourced and the effect of this on wages is a function of firm size, which will be reflected in a steeper decline in the FSWE for lower- and middle-wage workers relative to higher-wage workers.

To summarize, due to a combination of factors that heightened product market competition and increased financial market pressures, large U.S. employers undertook a number of strategies to enhance their operational flexibility, improve productivity, and lower labor costs. Some of these changes, including dismantling ILMs, relying on external market wage-setting practices, and 
redrawing firm boundaries, altered employment relations in ways that have been particularly detrimental to lower- and middle-wage workers relative to higher-wage ones. As such, we anticipate that the firm-size wage premium once earned by lower- and middle-wage workers will have declined to a greater extent than has the premium for higher-wage workers. Stated formally, we expect that:

Hypothesis 2: The firm-size wage effect has declined more rapidly for low-wage and mid-wage workers than for high-wage workers.

\section{The Firm-Size Wage Effect and Rising Wage Inequality}

To date, most research has focused on market-based accounts (e.g., Autor 2003; Bentele and Kenworthy 2013) or institutional explanations (e.g., Morris and Western 1999; Volscho 2005) for rising wage inequality. Though these theories have greatly enhanced our understanding of the causes for the rise, a significant amount of variance remains unexplained. A number of researchers have recently begun to try to address this gap by more fully discussing the role of organizations in rising income inequality (e.g., Cobb 2016; Davis and Cobb 2010; Sørensen 2007). Leveraging insights from the neostructuralist tradition of stratification studies (e.g., Baron and Bielby 1980), these researchers contend that organizations help determine labor market outcomes such as income inequality by providing unequal access to remuneration, rewards, and opportunities for advancement (Baron 1984; Kalleberg and Sørensen 1979; Spilerman 1977). In fact, studies have shown that nearly 40 percent of the total variation in wages emerges from similarly skilled workers being employed in firms that reward them differently (Abowd and Kramarz 1999).

The relevant studies in this area have largely examined how organizational demography in a labor market affects the distribution of income. Drawing upon sorting and matching theories (e.g., Hannan 1988; Roy 1951), Sørensen and Sorenson (2007) found that increased numbers of 
organizations in a region competing in the same industry lead to higher earnings inequality, whereas inequality is lower when firms in a region compete in a more diverse array of industries. Focusing specifically on firm size, Davis and Cobb (2010) theorized that although wages inside of large firms vary by hierarchical level, concerns for equity constrain the disjuncture from one level to the next. Such standardization compresses wages, thereby reducing wage dispersion within the firm. Moreover, standardized wage-setting systems tend to benefit lower- and middle-skilled individuals, who receive a greater wage premium than that their higher-skilled counterparts receive (Cappelli 2001; Nickerson and Zenger 2008). By raising the wage floor for those in lower and middle portions of the skill distribution, as more individuals are brought within the boundaries of large firms, wage inequality within the broader labor market will likely be lower.

Implicit in the studies on firm size and wage inequality, however, is the assumption that large firms have maintained their proclivity to compress wages. Yet, if large firms are no longer as actively compressing wages by providing a larger wage premium to lower- and middle-wage individuals than to higher-wage ones, we should expect that overall inequality to be greater than it would be had the wage-setting practices of large firms remained unchanged. Hence, if our above hypotheses are correct we should find evidence that rising wage inequality during this period in the United States can be partially explained by differential declines in the FSWE across the wage distribution.

\section{DATA AND METHODS}

\section{Data}

We used the Current Population Survey (CPS Annual Social and Economic Supplement files from 1988 to 2015 (King, Felin, and Whetten 2010) to examine how the FSWE changed over time and across wage distribution and to measure the total impact of changing FSWE on wage 
inequality. ${ }^{3}$ Because the CPS asks about earnings in the prior year, the reported earnings are for 1987 through 2014. The survey is based on random samples of U.S. households, so our results are representative of the U.S. working population. Our samples include full- and part-time employees aged 25-65 who worked in the private sector. Self-employed and governmental workers are excluded from the analysis since their earnings are less relevant to the theoretical questions at hand. In a supplementary analysis, we used the Survey of Income and Program Participation (SIPP) from 1996 to 2008, and the findings are substantively similar to those presented below (see Appendix B \& C). ${ }^{4}$

A common problem in using these surveys to study inequality is top-coding. The survey imputes the earnings of top earners to ensure anonymity, which prevents the researchers from accurately estimating the average wage effect. The proportion of earners who were top-coded slowly increased over time. For women, the number increased from 0.02 percent in 1975 to 0.86 percent in 2007; for men, the number increased from 1.18 percent to 2.59 percent (see Burkhauser and Larrimore 2009 for more discussion on this issue). Thus, this study was unable to examine the wage dynamics at the very top (e.g., 1 percent) of the distribution. However, because our scope of analysis was restricted to those at or below the 90th wage percentile, our findings were unaffected by top-coding.

\footnotetext{
${ }^{3}$ The annual CPS survey is preferable over the monthly CPS survey because it captures annual or quarterly bonuses, a crucial form of compensation for high-skilled workers.

${ }^{4}$ The SIPP provides more detailed information on workers' tenure, which is useful for teasing out the effects of this confounding factor. However, the survey only has three firm-size categories $(<25,25-99,100+)$ and is not updated as quickly as the CPS.
} 


\section{Variables}

Our dependent variable was the 2014 logged hourly wage, calculated as the inflation adjusted annual wage and salary earnings divided by annual work hours. The CPS specifically prompts the respondents to include overtime pay, tips, bonuses, and commissions, which helps ensure that these earnings are included in addition to one's base pay. We conducted additional analysis using logged annual earnings and unimputed earnings data to gauge the potential effects of work-hour polarization (Jacobs and Gerson 2005) and hot-deck imputation (Mouw and Kalleberg 2010). The results were substantively similar to the results presented below. Figure 1 presents logged wage growth at the 10th, 50th, and 90th percentiles and the interpercentile wage gaps. It shows that most wage growth in the past three decades took place during the 1990s economic boom. It also indicates that the overall wage inequality (90th-10th) has been increasing, largely driven by a widening gap in the upper half of the distribution (90th-50th). The wage disparity in the lower half (50th-10th) remains relatively stable around 0.8 logged point during this period.

\section{|---- Insert Figure 1 about Here ----|}

Our main explanatory variable was the total number of persons who worked for the respondent's employer during the preceding calendar year, counting all locations where the employer operated. Since individual respondents often did not have accurate information on how many people were employed in their firms, the variable was measured in broad categories. To produce consistent estimates across time, we assigned the CPS respondents into the following four groups: fewer than 100 employees, between 100 and 499 employees, between 500 and 999 
employees, and 1,000 or more employees. ${ }^{5}$ We identified the FSWE by estimating the logged wage difference between the latter three groups and the first group across the wage distribution.

Figure 2 presents the proportion of workers who worked in firms with fewer than 100,100 $499,500-999$, and 1,000 or more employees. It shows that about 40 percent of the private sector workers were employed by enterprises with fewer than 100 employees, around 16 percent were employed in firms with between 100 and 499 employees, and 6 percent were employed in business with 500 to 999 employees, while 37 percent were employed in firms with at least 1,000 employees. The pattern is largely stable in the period of analysis and the fluctuation for firms with 500-999 employees is mostly driven by its small share. However, we do see that the share of workers who were employed by firms with 1,000-plus employees increased around 7 percent compared to the 1987 level, while the share of firms with 100-499 employees declined about 13 percent. $^{6}$

|---- Insert Figure 2 about Here ----|

\footnotetext{
${ }^{5}$ The firm-size measure has changed two times between 1988 and 2015 in the CPS. The original 1988 categories included $<25,25-99,100-499,500-999$, and 1,000+. The first category was replaced with < 10 and 10-24 in 1992, and this latter category along with 25-99 was replaced with 10-49 and 50-99 in 2011. We created four consistent categories: fewer than 100, 100-499, 500-999, and 1,000 or more employees.

${ }^{6}$ Davis and Cobb (2010) found that between 1950 and 2010, the proportion of workers employed by the largest 10, 50, and 100 corporate employers declined. This discrepancy is most likely due to the fact that we are focusing on a shorter time period and our categorization of large firm size is much broader than was theirs.
} 
We included a series of confounding variables in our regression analysis. To ensure that the FSWE was not driven by human capital differences, we controlled for the level of education, age, and its squared term, which approximates worker skill. We also included union status to ensure our result was not driven by the deunionization of the U.S. workforce (Western and Rosenfeld 2011). To account for potential differences in geographical location between large and small firms, we controlled for the interaction terms between nine census divisions and metropolitan status. Additionally, we controlled for each respondent's racial background and the interaction terms between gender, marital, and parental status. In the supplementary analysis using the SIPP, we included tenure and its squared term. The results were substantively similar to our main findings. Descriptive statistics of all the variables used in our regression are presented in Appendix A.

Additionally, shifts in the industrial sectors in which large firms now compete may also play a role in shaping the FSWE. Notably, the largest U.S. corporate employers are no longer manufacturers such as General Motors, but instead are retailers like Wal-Mart. Unlike those in manufacturing and other industrial firms, lower-skilled workers in service-related occupations make lower wages and have fewer opportunities for advancement. To separate the FSWE from the migration of workers from manufacturing to service industries, we also included six dichotomous variables indicating whether the worker was in the natural resources, construction, manufacturing, transportation and utilities, wholesale and retail, or service industry.

\section{Model Specification}

We used re-centered influence function (RIF regressions (see Firpo, Fortin, and Lemieux 2009; Fortin et al. 2011; Lin 2015 for more discussion) to detect how the FSWE may vary across wage distribution. That is, we compared the logged wage differences among workers of different 
firm sizes who were otherwise similar in observed characteristics and location in the wage distribution. The logic of this method is based on the statistical concept of influence function - the relation between a data point and the statistics of interest, such as quantile, variance, or Gini coefficient. By recentering the influence function with statistics of interest and regressing each observation's recentered influence on the explanatory variables, one can estimate how these variables jointly shape the unconditional statistics of interest. In this light, the standard ordinary least squares (OLS) model could be viewed as an RIF regression, where the statistics of interest is the mean and the influence function is $\mathrm{Y}-\mu$, and the RIF is simply $\mathrm{Y}-\mu+\mu$. In the case of quantiles, the RIF for the $\tau$ th quantile is:

$$
R I F\left(y ; q_{\tau}\right)=\frac{\tau-\mathbb{1}\left\{y \leq q_{\tau}\right\}}{f_{Y}\left(q_{\tau}\right)}+q_{\tau}
$$

where $y$ denotes the observed outcome; $\mathbb{1}\left\{y \leq q_{\tau}\right\}$ is an indicator function, which equals 1 when $y$ is equal or smaller than $q_{\tau}$ and equals 0 otherwise; and $f_{Y}\left(q_{\tau}\right)$ is the probability density of $Y$ at $q_{\tau}$, which is approximated through a kernel function in the analysis. Put differently, we first estimate a series of linear probability models to obtain the influences of the explanatory variables on one's likelihood to be above or below a given quantile. We then divide the coefficients with the local probability density to obtain their marginal effects on wages.

Analytically, unconditional quantile regression provides significant advantages over more common estimation techniques. While standard regression compares mean differences, unconditional quantile regression allows researchers to estimate quantile-specific effects. This is a useful feature, especially as studies increasingly show that the effects of explanatory variables are rarely uniform throughout the distribution of outcomes. The best-known example in the research on inequality is the effect of union status on wages (Freeman 1980; Western and 
Rosenfeld 2011). Union workers earn more than nonunion workers, on average, but the positive effect diminishes for workers with higher wage potential and turns negative for workers at the top of the earnings distribution (see Fig. 6 in Lemieux 2008). Precisely because of this mean-reverting nature, union density tends to reduce wage inequality (Card 1996; Western and Rosenfeld 2011). Similarly, the effect of the minimum wage is salient at the bottom of the wage distribution but becomes negligible above the bottom (Autor, Manning, and Smith 2016; Neumark, Schweitzer, and Wascher 2004) and the effect of working in finance is greater at the top than the rest of the wage distribution (Lin 2015).

Figure 3 presents a series of hypothetical treatments to illustrate the idea of quantilespecific effects. $\beta 80, \beta 50$, and $\beta 20$, respectively, denote the marginal effects of a certain treatment on the 80th, 50th, and 20th percentiles of the unconditional distribution. This figure shows that treatment $\mathrm{A}$ has a homogeneous effect of 1 across the distribution $(\beta 80=\beta 50=\beta 20)$, which increases the mean from 0 to 1 without changing the level of dispersion. In this case, the OLS and the RIF regressions will both yield the identical estimate of 1 . Treatment B has a positive effect on the upper half of the distribution but a symmetrically negative effect on the lower half. In this case, the treatment does not shift the mean but increases the overall dispersion. The OLS regression will yield an estimate of 0 , while the RIF regression will yield an estimate of 1 at the 80th percentile and -1 at the 20th percentile. Treatment $\mathrm{C}$ has the opposite effect and thus contracts the distribution. Treatments $\mathrm{D}, \mathrm{E}$, and $\mathrm{F}$ all increase the mean by one unit, but respectively have the strongest effect on the top, the middle, and the bottom of the distribution. The case of treatment $\mathrm{D}$ is akin to the Matthew effect described by Merton (1968), that those who shall be given shall have abundance. The case of treatment $\mathrm{F}$, in contrast, is similar to the effect the minimum wage has on income distributions. 
It should be emphasized that the quantile estimates obtained by the RIF regression are different from those of the standard quantile regression (Hao and Naiman 2007; Koenker 2006; Koenker and Bassett 1978) The standard quantile regression obtains the coefficients through the asymmetrically weighted minimization of the residuals. Thus, the associations are estimated across the conditional or residual distribution. By contrast, the RIF regression approximates the effects at the unconditional quantiles, and the coefficients are thus more readily interpretable.

To examine the varying FSWE, we estimate the models as:

$$
R I F\left(y_{t, i} ; q_{\tau, t}\right)=\alpha_{\tau, t}+\sum_{j}^{J} \beta_{j, \tau, t} S_{j, t, i}+\sum_{k}^{K} \beta_{k, \tau, t} X_{k, t, i}+\varepsilon_{t, i}
$$

where $t$ denotes time period, $\tau$ denotes quantile, $i$ denotes individual, $S$ indicates the size of the firm where worker $i$ was employed, and $X$ denotes other controls in the models. The coefficients of interest that are associated with firm size are $\beta_{j, \tau, t}$. To detect how the FSWE changed over time, we estimated a series of year-centered, exponentially weighted equations to obtain "moving average" coefficients. Because the sample size differs by year, we first equalized the importance across years by assigning a year-specific inverse probability weight to each observation:

$$
W_{i, p}=1 / N_{p}
$$

where $W$ denotes the weight of observation $i$, and $N$ denotes the total number of observations in year $p$. To estimate the equation for year $q$, we further assigned an exponential weight to each observation based on the distance between $p$ and $q$. That is:

$$
W_{i, p, q}=\alpha^{|p-q|} W_{i, p}
$$

where $\alpha$ denotes the smoothing factor between 1 and 0 . We used 0.7 as the smoothing factor in the following analysis to detect broad trends. Although a smaller smoothing factor would be more 
responsive to sudden shifts, such shifts are not plausible for the social processes examined in this paper.

\section{RESULTS}

\section{Main Results}

Table 1 presents the partial coefficients and robust standard errors predicting logged wage at five wage percentiles from the pooled regression models for the years 1987 to 2014. (See Appendix B for substantively similar estimates using the SIPP). We first compare the coefficients across firms of different sizes, with those with fewer than 100 workers as the reference group. Consistent with the literature, we see that larger firms tend to pay higher wages even after accounting for human capital, supply-side, and other compositional differences. Nevertheless, the wage effect of size seems to diminish for low-wage workers once the firm reaches 500 workers. At the 10th and 25th percentiles of the wage distribution, we see that workers in firms with 500999 employees received a similar premium (0.188 and 0.184$)$ to those in firms with more than 1,000 employees ( 0.180 and 0.188$)$. This is not the case for median- and high-wage workers, whose premiums continue to rise. For instance, at the 90th percentile of the wage distribution, firms with 1,000 or more workers pay a premium of 17 percent, almost 10 percent more than that of firms with between 500 and 999 workers.

$$
\text { |---- Insert Table } 1 \text { about Here ----| }
$$

Table 1 also indicates that the FSWE varies significantly across the wage distribution. Consistent with our hypothesis, the wage premiums are greater for low- and median-wage workers and smaller for high-wage workers. For example, at the 10th percentile of the wage distribution, workers in firms with between 100 and 499 employees on average make about 16 percent more than those in firms with fewer than 100 employers, while the same comparison at the 90th 
percentile yields a size premium of 4.6 percent. Again, we see a difference between firms with 100-999 workers and those with 1,000 or more workers. For the former firms the wage premium is highest at the bottom of the wage distribution and declines upward, while for the latter firms, the premium increases from the bottom to the 75th percentile but drops at the upper end, which suggests that practices such as ILMs may be more prevalent among the largest firms, which reward their core workers progressively. These findings support Hypothesis 1 that the FSWE is larger for low-wage and mid-wage workers than for high-wage workers.

Human capital characteristics largely perform as expected. Workers with more education in general earn higher wages but the educational effects vary substantially based on the credential and the location of the wage distribution. Compared to workers without a high school diploma, those who completed high school have the greatest advantages at the lower end of distribution. Those with more than a college degree, in contrast, enjoy the greatest wage bump at the upper end. Age, a proxy of experience, has a positive effect on wages, and its effect is strongest in the middle of the wage distribution. Consistent with previous findings, unionization has the strongest wage effect in the middle of the wage distribution but reduces wages at the very top.

\section{Temporal Variation}

After examining how the FSWE varies across wage distribution, we proceed to investigate how these patterns change over time with a series of year-centered (1987-2014) and quantilespecific (10th, 25th, 50th, 75th, and 90th) regression models, which yield a total of 140 sets of estimates. Below we only present the coefficients of three firm-size categories graphically. Other estimates are available upon request. The same procedure is also used to analyze the SIPP, which yields similar results. (See Appendix C for the SIPP estimates.) 
Figure 4 presents the year-centered regression results from the CPS between 1987 and 2014, where the shading areas represent the 95-percent confidence intervals. Similar to the results presented in Table 1, we see that firm size is positively associated with the FSWE. That is, those employed by larger firms tend to receive higher wages. Furthermore, the size premiums tend to be larger for low- or median-wage workers than high-wage workers. However, Figure 4 also shows that the FSWE for low-wage workers declined sharply between 1987 and 2000. For those at the 10th percentile of the wage distribution, the FSWE dropped from 19 percent (100-499), 24 percent (500-999) and 23 percent (1000+) in 1987 to 14 percent (100-499), 16 percent (500-999) and 16 percent (1000+) in 2014. Conversely, the FSWEs for high-wage workers (75th and 90th percentiles) remained stable in the period of analysis. Workers at the 90th percentile employed by firms with 1,000 or more workers even experienced a moderate but statistically non-significant increase in recent years. As a result, they received a larger size premium than those at the bottom of the wage distribution $(p<0.001)$. Overall, Figure 4 suggests that the FSWE was greater for lowor median-wage workers in the earlier period but has been converging over time, mostly driven by the declines of those who received larger premiums in the earlier period.

\section{|---- Insert Figure 4 about Here ----|}

\section{The FSWE and Wage Inequality}

Since the decline in the FSWE has been disproportionally concentrated among low- and middle-wage workers, the consequence is a higher level of wage inequality. To account how much of the rising wage inequality is driven by the convergence of the FSWE, we calculate counterfactual wage trends for the 90 th, 50th, and 10th percentiles respectively by holding the net FSWE (i.e., the wage gaps between those with fewer than 100 employers and the other three categories) at its 1987 level. In other words, we ask what the level of inequality would be if there 
had been no change in the FSWE. The differences between the observed (Figure 1) and counterfactual inequality therefore could be interpreted as the part of inequality growth explained by the FSWE.

\section{|---- Insert Figure 5 about Here ----|}

Figure 5 presents the observed and counterfactual trends for the 90th-10th and 90th-50th logged wage gaps. It shows that the observed wage gap between the 90th and the 10th percentile grew from 1.61 to 1.74 in the period of interest, a difference of 0.13 logged point. The counterfactual trend also increased about 0.09 point, which indicates the FSWE could account for around 32 percent of the growth in 90th-10th wage inequality. The observed wage gap between the 90 th and the 50th percentiles, on the other hand, rose from 0.77 to 0.92 , while the counterfactual trend increased to only 0.88 . Thus, around 21 percent of the growth in 90 th-50th wage inequality is driven by the FSWE. In sum, the analysis here shows that the FSWE played a significant role in the rising wage inequality in the United States between 1987 and 2014.

\section{DISCUSSION}

Over the past several decades, there has been a general trend of rising levels of wage inequality in the United States. While prior research has offered important insights into the roles played by human capital characteristics, market forces, and institutional changes for this rise, less attention has been afforded to the study of how firms affect wage inequality in the broader labor market. Yet, firms are of great importance to the study of inequality because they make decisions about who to hire, how much to pay, and how many to employ (Baron, 1984). In this study, we complement and extend existing research on wage inequality by offering an organizationalcentered account for its rise. Drawing upon research on the FSWE and changing employment 
dynamics, we develop a set of arguments for why declines in the FSWE might be more pronounced for those at the bottom and middle of the wage distribution than for those at the top.

Specifically, we argue that while historically, large firms were prone to compress wages by paying lower- and middle-skilled workers a greater wage premium than their higher-skilled and thus higher-wage workers, recent trends in employment relations have likely undermined low-and mid-skilled workers' ability to still obtain such a premium. The results of our analyses show a relatively steep decline in the FSWE for those between the 10th and 75th percentiles of the wage distribution. Conversely, our findings indicate that the FSWE has remained relatively constant for workers at the 90th percentile of earnings employed in firms with 100-499 and 500-999 employees and that the FSWE has increased modestly for comparable workers employed by firms with at least 1,000 workers. Hence a portion of rising wage inequality in the United States between 1987 and 2014 can be explained by changes in the FSWE during this period.

Our study contributes to sociological inquiries into the FSWE and studies of inequality in several ways. First, prior work on the FSWE has concentrated primarily on attempting to account for its existence (e.g., Fox 2009; Idson and Oi 1999) and/or account for its decline (e.g., Even and Macpherson 2012; Hollister 2004). In this study, we took a different approach and examined whether previously documented declines in the FSWE are concentrated among lower- and middlewage workers. We find strong evidence to support these claims. Our results also indicate some increase in the FSWE for individuals at the 90th percentile of the wage distribution who are employed by firms with at least 1,000 workers. This is to our knowledge the first study to examine the distributional consequences of changes in the FSWE. Our study therefore points to the importance of examining not only the causes of the FSWE but also the consequences of its decline. 
Second and relatedly, sociological inquiry has long been directed toward studying how firm size affects stratification outcomes (e.g., Blau and Schoenherr 1971; Kalleberg and Van Buren 1996; Villemez and Bridges 1988). We continue that tradition by analyzing how changes in the FSWE may differ across the wage distribution and linking these differential changes to rising wage inequality. Recent work has also explored the relationship between large-firm employment and societal rates of income inequality (e.g., Davis and Cobb 2010); however, this work implicitly assumes that the wage-setting practices of large firms have held relatively constant. Our study builds on this research by showing that, on average, large firms are seemingly less willing to compress wages by providing their lower- and middle-wage employees a larger wage premium than that received by their higher-wage counterparts. Hence, the findings here suggest that the relationship between large-firm employment and wage inequality as documented in these prior studies has likely weakened over time.

In a related vein, we complement and extend existing research on firms and inequality. In recent years, a number of scholars have argued that the reasons for the dramatic rise in wage inequality over the past several decades can be traced to changes in corporate employment (e.g., Barth et al. 2014; Cobb 2016; Song et al. 2015). Yet, sociological inquiry into rising wage inequality has largely neglected the role of firms (see McCall 2004; Sørensen 2007). We see this as a particularly significant oversight given the importance given to the role of firms in earlier studies of stratification (e.g., Kalleberg and Van Buren 1996; Stolzenberg 1978). In particular, the neo-structuralist stratification perspective persuasively argued that through their decisions regarding the allocation of jobs, how to reward workers for their labor, and where they place their boundaries, organizations play a key role in how income is stratified (Baron and Bielby 1980). Following this tradition, we find evidence that large firms are no longer as actively compressing 
wages, thereby placing organizations at the center of the debate on rising wage inequality. While changes in the FSWE, and employment practices more broadly, are not the sole determinant of wage inequality, they play an important yet understudied role. Accounting for the ways in which these practices influence inequality has the potential to enrich our understanding of the dynamics undergirding wage differentials.

Finally, our study also has implications for the study of changing employment relations. A number of important studies have documented factors that have led to fundamental alterations in employment and inequality, including globalization (Alderson and Nielsen 2002), technological change (Acemoglu 2002), financialization (Lin 2013; Lin and Tomaskovic-Devey 2013), and shareholder pressures (Cobb 2015; Jung 2015). Further, other studies have focused squarely on changes in employment practices, including the decline in ILMs (Cappelli 2001), new wagesetting practices (Lemieux et al. 2009), the increased use of external hiring (Bidwell 2011), and the rise of nonstandard work arrangements (Ashford, George, and Blatt 2007; Cappelli and Keller 2013). In this study, we leveraged insights from this work to develop a set of arguments for how changes in the employment relationship have played out in terms of the FSWE. In so doing, we offer suggestive evidence that many of the changes documented in these studies have altered the economic returns of large-firm employment and have played a role in rising levels of wage inequality within the United States.

Our study is not without limitations that point to directions for future research, however. As we alluded to above, the FSWE is commonly thought to be a proxy for one or more factors that are difficult to observe with existing data (Hollister 2004). That limitation is relevant in our study as we cannot directly test the factors we believe might be responsible for the differential declines in the FSWE throughout the wage distribution. Notably, we have argued that the decline of ILMs, 
changes in organizational wage-setting practices, and the use of outsourcing and other nonstandard work arrangements weaken the ability of lower- and middle-wage workers to obtain a larger firmsize wage premium than their higher-wage counterparts. However, we cannot directly observe why the FSWE has declined and why it has declined more steeply for those at the lower and middle portions of the wage distribution. In the future, researchers may be able to leverage large-scale, organizational-level (i.e., matched employer-employee) data to better test the mechanisms proposed in this study. Additionally, researchers may also fruitfully explore whether the same dynamics found in this study hold in other countries. Given the vast differences in the ways in which employment relations are structured around the world (Amable 2003; Jacoby 2005), studies of other countries and cross-national comparisons may yield important insights on the role largefirm employment plays in different institutional and economic contexts.

In a related vein, we recognize the fact that declines in the FSWE among low- and midwage workers may be a proximal mechanism affecting wage inequality through which other, distal factors - such as globalization, technological change, and union declines-operate. Still, the findings suggest changes in large firms' wage-setting practices play an important mediating role in how these other factors get translated into employment outcomes. Moreover, even if other factors are ultimately driving rising wage inequality, our results suggest that these factors are affecting the wage-setting systems in large firms more than in small ones, which has important implications for our understanding of how broader changes in the market and institutional environment are affecting employment relationships. Future work may be able to explore more fully the factors causing the FSWE to decline more rapidly for low- and mid-wage workers and to examine how factors previously cited as driving changing employment relations affect wage setting inside large firms. 


\section{REFERENCES}

Abowd, John M. and Francis Kramarz. 1999. "The Analysis of Labor Markets Using Matched Employer-Employee Data.” Pp. 2629-2710 in Handbook of Labor Economics, edited by O. Ashenfelter and D. Card. Amsterdam, Netherlands: North-Holland.

Acemoglu, Daron. 2002. “Technical Change, Inequality, and the Labor Market.” Journal of Economic Literature 40(1):7-72.

Alderson, Arthur S. and Francois Nielsen. 2002. "Globalization and the Great U-Turn: Income Inequality Trends in 16 OECD Countries." American Journal of Sociology 107(5):124499.

Aldrich, Howard E. and Peter V. Marsden. 1988. "Environments and Organizations.” Handbook of Sociology 1:361-92.

Amable, Bruno. 2003. The Diversity of Modern Capitalism. Oxford, UK: Oxford University Press.

Ashford, Susan J., Elizabeth George, and Ruth Blatt. 2007. "Old Assumptions, New Work: The Opportunities and Challenges of Research on Nonstandard Employment." Academy of Management Annals 1:65-117.

Autor, David H. 2003. "Outsourcing at Will: The Contribution of Unjust Dismissal Doctrine to the Growth of Employment Outsourcing." Journal of Labor Economics 21:1-42.

Autor, David H., Alan Manning, and Christopher L. Smith. 2016. "The Contribution of the Minimum Wage to US Wage Inequality over Three Decades: A Reassessment." American Economic Journal: Applied Economics 8(1):58-99.

Avent-Holt, Dustin and Donald Tomaskovic-Devey. 2014. "A Relational Theory of Earnings Inequality." American Behavioral Scientist 58:379-99.

Bandiera, Oriana, Iwan Barankay, and Imran Rasul. 2007. "Incentives for Managers and Inequality among Workers: Evidence from a Firm-Level Experiment." Quarterly Journal of Economics 122:729-73.

Baron, James N. 1984. "Organizational Perspectives on Stratification." Annual Review of Sociology 10:37-69.

Baron, James N. and William T. Bielby. 1980. "Bringing the Firms Back in: Stratification, Segmentation, and the Organization of Work." American Sociological Review 45:737-65.

Baron, James N. and William T. Bielby. 1984. "The Organization of Work in a Segmented Economy.” American Sociological Review 49(4):454-73. 
Barth, Erling, Alex Bryson, James C. Davis, and Richard Freeman. 2014. It's Where You Work: Increases in Earnings Dispersion across Establishments and Individuals in the U.S. National Bureau of Economic Research. Retrieved May 17, 2016 (http://www.nber.org/papers/w20447).

Batt, Rosemary, Alex Colvin, and Jeffrey Keefe. 2002. "Employee Voice, Human Resource Practices, and Quite Rates: Evidence from the Telecommunications Industry." Industrial and Labor Relations Review 55(4):573-94.

Becker, Gary S. 1964. Human Capital: A Theoretical and Empirical Analysis, with Special Reference to Education. New York: National Bureau of Economic Research.

Bell, Brian and John Van Rennen. 2014. "Bankers and Their Bonuses." The Economic Journal 124(574):1-21.

Bentele, Keith G. and Lane Kenworthy. 2013. "Globalization and Earnings Inequality in the United States.” Pp. 343-58 in The Economics of Inequality, Poverity and Disrimination in the 21st Century, edited by R. Rycroft. Santa Barbara, CA: Prager.

Bernhardt, Annette, Rosemary Batt, Susan N. Houseman, and Eileen Appelbaum. 2016. "Domestic Outsourcing in the U.S.: A Research Agenda to Assess Trends and Effects on Job Quality."

Bidwell, Matthew J. 2011. "Paying More to Get Less: The Effects of External Hiring versus Internal Mobility." Administrative Science Quarterly 56:369-407.

Bidwell, Matthew J. 2013. "What Happened to Long-Term Employment? The Role of Worker Power and Environmental Turbulence in Explaining Declines in Worker Tenure." Organization Science 24:1061-82.

Bidwell, Matthew J., Forrest Briscoe, Isabel Fernandez-Mateo, and Adina Sterling. 2013. "The Employment Relationship and Inequality: How and Why Changes in Employment Practices Are Reshaping Rewards in Organizations." Academy of Management Annals 7:61-121.

Blau, Peter M. and Richard A. Schoenherr. 1971. The Structure of Organizations. New York: Basic Books.

Brown, Charles, James Hamilton, and James L. Medoff. 1990. Employers Large and Small. Harvard University Press.

Brown, Charles and James Medoff. 1989. "The Employer Size-Wage Effect.” Journal of Political Economy 97(5):1027-59.

Burkhauser, Richard V. and Jeff Larrimore. 2009. "Trends in the Relative Household Income of Working-Age Men with Work Limitations: Correcting the Record Using Internal Current Population Survey Data.” Journal of Disability Policy Studies 20(3):162-69. 
Cappelli, Peter et al. 1997. Changes at Work. New York: Oxford University Press.

Cappelli, Peter. 1999. The New Deal at Work: Managing the Market-Driven Workforce. Boston, MA: Harvard University Press.

Cappelli, Peter. 2001. "Assessing the Decline of Internal Labor Markets.” Pp. 207-45 in Sourcebook of labor markets: Evolving structures and processes, edited by I. Berg and A. L. Kalleberg. New York: Kluwer Academic/Plenum Publishers.

Cappelli, Peter and Keith W. Chauvin. 1991. "An Interplant Test of the Efficiency Wage Hypothesis.” Quarterly Journal of Economics 106:769-87.

Cappelli, Peter and J. R. Keller. 2013. "A Study of the Extent and Potential Causes of Alternative Employment Arrangements." ILR Review 66:874-901.

Card, David. 1996. "The Effect of Unions on the Structure of Wages: A Longitudinal Analysis." Econometrica 64(4):957-79.

Chauvin, Keith W. 1992. "The Declining Returns to Tenure for Managerial Jobs.” Managerial Economics 15:21-37.

Child, John. 1972. "Organizational Structure, Environment and Performance: The Role of Strategic Choice." Sociology-the Journal of the British Sociological Association 6:1-22.

Cobb, J.Adam. 2015. "Risky Business: Firms' Shifting of Retirement Risk and the Decline of Defined Benefit Pension Plans." Organization Science 26:1332-50.

Cobb, J.Adam. 2016. "How Firms Shape Income Inequality: Stakeholder Power, Executive Decision-Making, and the Structuring of Employment Relationships." Academy of Management Review 41:324-48.

Criscuolo, Chiara. 2000. Employer Size - Wage Effect: A Critical Review and an Econometric Analysis. Rochester, NY: Social Science Research Network. Retrieved September 10, 2015 (http://papers.ssrn.com/abstract=223546).

Crispin, Gerry and Mark Mehler. 2013. Source of Hire 2013: Perception Is Reality. Retrieved (http://www.careerxroads.com/news/SourcesOfHire2013.pdf).

Dalton, James A. and E. J. Ford. 1977. "Concentration and Labor Earnings in Manufacturing and Utilities." Industrial and Labor Relations Review 31(1):45-60.

Davis, Gerald F. 2009a. Managed by Markets: How Finance Reshaped America. New York: Oxford University Press USA.

Davis, Gerald F. 2009b. "The Rise and Fall of Finance and the End of the Society of Organizations." Academy of Management Perspectives 23:27-44. 
Davis, Gerald F. and J.Adam Cobb. 2010. "Corporations and Economic Inequality around the World: The Paradox of Hierarchy." Research in Organizational Behavior 30:35-53.

Davis-Blake, Alison and Joseph P. Broschak. 2009. "Outsourcing and the Changing Nature of Work." Annual Review of Sociology 35:321-40.

Dencker, John C. and Chichun Fang. 2016. "Rent Seeking and the Transformation of Employment Relationships The Effect of Corporate Restructuring on Wage Patterns, Determinants, and Inequality." American Sociological Review 3122416642419.

DiNardo, John E., Nicole M. Fortin, and Thomas Lemieux. 1996. "Labor Market Institutions and the Distribution of Wages, 1973-1992: A Semiparametric Approach.” Econometrica 64:1001-44.

DiPrete, Thomas A., D. Goux, and E. Maurin. 2002. "Internal Labor Markets and Earnings Trajectories in the Post-Fordist Economy: An Analysis of Recent Trends." Social Science Research 31:175-96.

Dobbin, Frank and J. Jung. 2010. "The Misapplication of Mr. Michael Jensen: How Agency Theory Brought Down the Economy and Why It Might Again." Markets on Trial: The Economic Sociology of the U.S. Financial Crisis (Research in the Sociology of Organizations) 30B:29-64.

Dobbin, Frank R., John R. Sutton, John W. Meyer, and W.Richard Scott. 1993. "Equal Opportunity Law and the Construction of Internal Labor Markets." American Journal of Sociology 99:396-427.

Doeringer, Peter B. and Michael J. Piore. 1971. Internal Labor Markets and Manpower Analysis. Lexington, MA: Heath.

Dube, Arindrajit and Ethan Kaplan. 2010. "Does Outsourcing Reduce Wages in the Low-Wage Service Occupations? Evidence from Janitors and Guards." Industrial \& Labor Relations Review 63:287-306.

Dulebohn, James H. and Stephen E. Werling. 2007. "Compensation Research Past, Present, and Future.” Human Resource Management Review 17:191-207.

El-Attar, Mayssun and Enrique Lopez-Bazo. n.d. "Firm Size and the Entire Distribution of Wages: A Semiparametric Approach.” Applied Economic Letters 15(6):427-30.

Evans, David S. and Linda S. Leighton. 1989. “Why Do Smaller Firms Pay Less?” The Journal of Human Resources 24(2):299-318.

Even, William E. and David A. Macpherson. 2012. "Is Bigger Still Better? The Decline of the Wage Premium at Large Firms.” Southern Economic Journal 78:1181-1201.

Firpo, Sergio, Nicole M. Fortin, and Thomas Lemieux. 2009. "Unconditional Quantile Regressions." Econometrica 77(3):953-73. 
Fortin, Nicole M., Thomas Lemieux, and Sergio Firpo. 2011. "Chapter 1 - Decomposition Methods in Economics." Pp. 1-102 in Handbook of Labor Economics, vol. Volume 4, Part A, edited by Orley Ashenfelter and David Card. Elsevier. Retrieved April 18, 2013 (http://www.sciencedirect.com/science/article/pii/S0169721811004072).

Fox, Jeremy T. 2009. "Firm-Size Wage Gaps, Job Responsibility, and Hierarchical Matching." Journal of Labor Economics 27(1):83-126.

Freeman, Richard B. 1980. "Unionism and the Dispersion of Wages." Industrial \& Labor Relations Review 34:3-23.

Garen, J. E. 1985. "Worker Heterogeneity, Job Screening, and Firm Size.” Journal of Political Economy 93:715-39.

Garicano, Luis and Estaban Rossi-Hansberg. 2006. "Organization and Inequality in a Knowledge Economy.” Quarterly Journal of Economics 121:1383-1435.

Granovetter, Mark. 1981. "Toward a Sociological Theory of Income Differences.” Pp. 11-47 in Sociological Perspectives on Labor Markets, edited by I. Berg. New York: Academic Press.

Groshen, Erica L. and David I. Levine. 1998. The Rise and Decline(?) Of U.S. Internal Labor Markets.

Hacker, Jacob S. 2008. The Great Risk Shift: The New Economic Insecurity and the Decline of the American Dream. New York, NY: Oxford University Press.

Hannan, Michael T. 1988. "Social Change, Organizational Diversity, and Individual Careers." Pp. 161-74 in Social change, organizational diversity, and individual careers, edited by M. W. Riley. Newbury Park, CA: Sage and the American Sociological Association.

Hao, Lingxin and Daniel Q. Naiman. 2007. Quantile Regression. SAGE Publications, Incorporated.

Heneman, Robert L. and Jon M. Werner. 2005. Merit Pay: Linking Pay to Performance in a Changing World.

Hertz, Rosanna. 2010. "Economic Crisis and New Social Realities: Bait and Switch and the American Dream-Presidential Address 2010.” Sociological Forum 25(4):643-54.

Hodson, Randy and Robert L. Kaufman. 1982. "Economic Dualism: A Critical Review." American Sociological Review 47(6):727-39.

Hollister, Matissa N. 2004. "Does Firm Size Matter Anymore? The New Economy and Firm Size Wage Effects." American Sociological Review 69(5):659-79. 
Houseman, Susan N., Arne L. Kalleberg, and George A. Erickcek. 2003. "The Role of Temporary Agency Employment in Tight Labor Markets." Industrial \& Labor Relations Review 57(1):105-27.

Idson, Todd L. and Walter Y. Oi. 1999. "Workers Are More Productive in Large Firms." American Economic Review 89(2):104-8.

Jacobs, Jerry A. and Kathleen Gerson. 2005. The Time Divide: Work, Family, and Gender Inequality. Cambridge, MA: Harvard University Press.

Jacoby, Sanford M. 1985. Employing Bureaucracy: Managers, Unions, and the Transformation of Work in American Industry. New York: Columbia University Press.

Jacoby, Sanford M. 1997. Modern Manors: Welfare Capitalism Since the New Deal. Princeton, NJ: Princeton University Press.

Jacoby, Sanford M. 2005. The Embedded Corporation: Corporate Governance and Employment Relations in Japan and the United States. Princeton, NJ: Princeton University Press.

Jung, Jiwook. 2015. "Shareholder Value and Workforce Downsizing, 1981-2006." Social Forces 93(4):1335-68.

Kalleberg, Arne L. and Aage B. Sørensen. 1979. "Sociology of Labor-Markets.” Annual Review of Sociology 5:351-79.

Kalleberg, Arne L. and Mark E. Van Buren. 1994. "The Structure of Organizational Earnings Inequality.” American Behavioral Scientist 37:930-47.

Kalleberg, Arne L. and Mark E. Van Buren. 1996. "Is Bigger Better? Explaining the Relationship between Organization Size and Job Rewards." American Sociological Review 61:47-66.

Kimberly, John R. 1976. "Organizational Size and the Structuralist Perspective: A Review, Critique, and Proposal." Administratie Science Quarterly 1:571-97.

King, Brayden G., Teppo Felin, and David A. Whetten. 2010. "Finding the Organization in Organizational Theory: A Meta-Theory of the Organization as a Social Actor." Organization Science 21:290-305.

Knoke, David and Arne L. Kalleberg. 1994. "Job Training in U.S. Organizations.” American Sociological Review 59(4):537-46.

Kochan, T. A. and C. A. Riordan. 2016. "Employment Relations and Growing Income Inequality: Causes and Potential Options for Its Reversal.” Journal of Industrial Relations 58(3):419-40.

Koenker, Roger. 2006. "Quantile Regresssion.” in Encyclopedia of Environmetrics. John Wiley \& Sons, Ltd. Retrieved April 18, 2013 
(http://onlinelibrary.wiley.com.silk.library.umass.edu/doi/10.1002/9780470057339.vnn09 $1 /$ abstract).

Koenker, Roger and Gilbert Bassett. 1978. “Regression Quantiles.” Econometrica 46(1):33-50.

Kunda, Gideon, Stephen R. Barley, and James Evans. 2002. "Why Do Contractors Contract? The Experience of Highly Skilled Technical Professionals in a Contingent Labor Market." Industrial \& Labor Relations Review 55:234-61.

Lemieux, Thomas. 2008. “The Changing Nature of Wage Inequality.” Journal of Population Economics 21:21-48.

Lemieux, Thomas, W.Bentley MacLeod, and Daniel Parent. 2009. "Performance Pay and Wage Inequality." Quarterly Journal of Economics 124:1-49.

Lepak, David P. and Scott A. Snell. 1999. "The Human Resource Architecture: Toward a Theory of Human Capital Allocation and Development." Academy of Management Journal 24:31-48.

Lichtenstein, Nelson. 2002. State of the Union: A Century of American Labor. Princeton, NJ: Princeton University Press.

Lin, Ken-Hou. 2013. The Rise of Finance and Firm Employment Dynamics, 1982-2005. Rochester, NY: Social Science Research Network. Retrieved December 7, 2015 (http://papers.ssrn.com/abstract=2284507).

Lin, Ken-Hou. 2015. "The Financial Premium in the US Labor Market: A Distributional Analysis.” Social Forces 94(1):1-30.

Lin, Ken-Hou and Donald Tomaskovic-Devey. 2013. "Financialization and US Income Inequality, 1970-2008.” American Journal of Sociology 118:1284-1329.

Lluis, Stéphanie. 2009. The Structure of Wages by Firm Size: A Comparison of Canada and the USA. Rochester, NY: Social Science Research Network. Retrieved May 17, 2016 (http://papers.ssrn.com/abstract=1406771).

Lowenstein, Roger. 1997. "Remember When Companies Actually Created Products?" The Wall Street Journal, September 18.

Matusik, Sharon F. and Charles W. L. Hill. 1998. "The Utilization of Contingent Work, Knowledge Creation, and Competitive Advantage." Academy of Management Review 23:680-97.

McCain, Mary. 2009. Serving Students: A Survey of Contracted Food Service Work in New Jersey's K-12 Public Schools. New Jersey: Rutgers Center for Womena nd Work.

McCall, Leslie. 2004. "The Impact of Organizational Changes on Aggregate Inequality: The Case of Downsizing." 
Mellow, W. 1982. "Employer Size and Wages." Review of Economics and Statistics 64:495-501.

Moore, Henry L. 1911. Laws of Wages: An Essay in Statistical Economics. New York: Augustus M. Kelley.

Morris, Martina and Bruce Western. 1999. "Inequality in Earnings at the Close of the Twentieth Century." Annual Review of Sociology 25:623-57.

Mouw, Ted and Arne L. Kalleberg. 2010. "Occupations and the Structure of Wage Inequality in the United States, 1980s to 2000s." American Sociological Review 75:402-31.

Neumark, David, Mark Schweitzer, and William Wascher. 2004. "Minimum Wage Effects throughout the Wage Distribution." Journal of Human Resources XXXIX(2):425-50.

Nickell, S., J. Vainiomaki, and S. Wadhwani. 1994. "Wages and Product Market Power." Economica 61(244):457-73.

Nickerson, Jack A. and Todd R. Zenger. 2008. "Envy, Comparison Costs, and the Economic Theory of the Firm." Strategic Management Journal 29:1429-49.

Oi, Walter Y. 1983. "The Fixed Employment Costs of Specialized Labor.” Pp. 63-122 in The Measurement of Labor Cost. University of Chicago.

Oi, Walter Y. and Todd L. Idson. 1999. "Firm Size and Wages." Pp. 2165-2214 in Handbook of Labor Economics, vol. 3, edited by O. Ashenfelter and D. Card. Amsterdam: Elsevier Science B.V.

Osterman, Paul S. 1999. Securing Prosperity: The American Labor Market: How It Has Changed and What to Do about It. Princeton, NJ: Princeton University Press.

Osterman, Paul S., Thomas A. Kochan, Richard M. Locke, and Michael J. Piore. 2001. Working in America: A Blueprint for the New Labor Market. Cambridge, MA: MIT Press.

Pedace, Roberto. 2010. "Firm Size-Wage Premiums: Using Employer Data to Unravel the Mystery." Journal of Economic Issues 44(1):163-82.

Pfeffer, Jeffrey and Alison Davis-Blake. 1992. "Salary Dispersion, Location in the Salary Distribution, and Turnover among College Administrators." Industrial \& Labor Relations Review 45:753-63.

Piore, Michael J. 2002. "Thirty Years Later: Internal Labor Markets, Flexibility and the New Economy." Journal of Management and Governance 6:271-79.

Raff, Daniel M. G. and Lawrence H. Summers. 1987. "Did Henry Ford Pay Efficiency Wages." Journal of Labor Economics 5:S57-86. 
Rawley, Evan and Timothy S. Simcoe. 2010. "Diversification, Diseconomies of Scope, and Vertical Contracting: Evidence from the Taxicab Industry." Management Science 56:1534-50.

Roy, A. D. 1951. "Some Thoughts on the Distribution of Earnings." Oxford Economic Papers 3:135-46.

Sanchez, Juan I. and Edward L. Levine. 2012. "The Rise and Fall of Job Analysis and the Future of Work Analysis.” Annual Review of Psychology, Vol 63 63:397-425.

Schmidt, Frank L. and John E. Hunter. 1981. "Employment Testing: Old Theories and New Research Findings.” American Psychologist 36:1128-37.

Schweiker, Michael and Martin Groß. 2016. "Organizational Environments and Bonus Payments: Rent Destruction or Rent Sharing?” Research in Social Stratification and Mobility.

Song, Jae, David J. Price, Fatih Guvenen, and Nicholas Bloom. 2015. "Firming Up Inequality."

Sørensen, Aage B. 2000. "Toward a Sounder Basis for Class Analysis." American Journal of Sociology 105:1523-58.

Sørensen, Jesper B. 2007. “Organizational Diversity, Labor Markets, and Wage Inequality.” American Behavioral Scientist 50:659-76.

Sørensen, Jesper B. and Olav Sorenson. 2007. "Corporate Demography and Income Inequality." American Sociological Review 72:766-83.

Spilerman, Seymour. 1977. "Careers, Labor-Market Structure, and Socioeconomic Achievement.” American Journal of Sociology 83:551-93.

Stolzenberg, Ross M. 1978. "Bringing Boss Back in: Employer Size, Employee Schooling, and Socioeconomic Achievement.” American Sociological Review 43:813-28.

Sun, H. Y. and GiSeung Kim. 2014. "Longitudinal Evidence of Firm Size Effect on Wage Premium and Wage Differential in Korean Labor Market." International Journal of Economic Sciences 3(3):66-85.

Tomaskovic-Devey, Donald and Ken-Hou Lin. 2011. "Income Dynamics, Economic Rents, and the Financialization of the U.S. Economy.” American Sociological Review 76:538-59.

Troske, Kenneth R. 1999. "Evidence on the Employer Size-Wage Premium from WorkerEstablishment Matched Data." Review of Economics and Statistics 81(1):15-26.

Villemez, Wayne J. and William P. Bridges. 1988. "When Bigger Is Better: Differences in the Individual-Level Effect of Firm and Establishment Size." American Sociological Review 53(2):237-55. 
Volscho, Jr. 2005. "Minimum Wages and Income Inequality in the American States, 19602000." Research in Social Stratification and Mobility 23:343-68.

Western, Bruce and Jake Rosenfeld. 2011. "Unions, Norms, and the Rise in U.S. Wage Inequality." American Sociological Review 76:513-37.

Yellen, Janet L. 1984. "Efficiency Wage Models of Unemployment.” American Economic Review 74:200-205.

Zenger, Todd R. 1994. "Explaining Organizational Diseconomies of Scale in R\&D: Agency Problems and the Allocation of Engineering Talent, Ideas, and Effort by Firm Size." Management Science 40:708-29. 
Table 1. Partial Coefficients and Robust Standard Errors Predicting Logged Wage Percentiles, 1987-2014

\begin{tabular}{|c|c|c|c|c|c|}
\hline & 10th & 25th & 50th & 75th & 90th \\
\hline \multicolumn{6}{|l|}{ Firm Size } \\
\hline \multicolumn{6}{|l|}{ (<100 Workers) } \\
\hline \multirow[t]{2}{*}{$100-499$} & $0.157 * * *$ & $0.140 * * *$ & $0.121 * * *$ & $0.086 * * *$ & $0.046 * * *$ \\
\hline & $(0.003)$ & $(0.002)$ & $(0.002)$ & $(0.002)$ & $(0.003)$ \\
\hline \multirow[t]{2}{*}{$500-999$} & $0.188 * * *$ & $0.184^{* * *}$ & $0.171 * * *$ & $0.141^{* * *}$ & $0.079 * * *$ \\
\hline & $(0.004)$ & $(0.003)$ & $(0.003)$ & $(0.004)$ & $(0.005)$ \\
\hline \multirow[t]{2}{*}{$1000+$} & $0.180 * * *$ & $0.188 * * *$ & $0.217^{* * *}$ & $0.231^{* * *}$ & $0.176^{* * *}$ \\
\hline & $(0.002)$ & $(0.002)$ & $(0.002)$ & $(0.002)$ & $(0.003)$ \\
\hline \multicolumn{6}{|l|}{ Human Capital } \\
\hline \multicolumn{6}{|c|}{ (Less than High School) } \\
\hline \multirow[t]{2}{*}{ High School } & $0.355^{* * *}$ & $0.331 * * *$ & $0.218 * * *$ & $0.111^{* * *}$ & $0.042 * * *$ \\
\hline & $(0.005)$ & $(0.003)$ & $(0.002)$ & $(0.002)$ & $(0.002)$ \\
\hline \multirow[t]{2}{*}{ Some College } & $0.484 * * *$ & $0.505^{* * *}$ & $0.412 * * *$ & $0.273^{* * *}$ & $0.151 * * *$ \\
\hline & $(0.005)$ & $(0.003)$ & $(0.003)$ & $(0.002)$ & $(0.003)$ \\
\hline \multirow[t]{2}{*}{ College } & $0.575^{* * *}$ & $0.661 * * *$ & $0.696 * * *$ & $0.675^{* * *}$ & $0.619 * * *$ \\
\hline & $(0.005)$ & $(0.003)$ & $(0.003)$ & $(0.003)$ & $(0.004)$ \\
\hline \multirow[t]{2}{*}{ Advanced Degree } & $0.569 * * *$ & $0.685 * * *$ & $0.811 * * *$ & $0.978 * * *$ & $1.220 * * *$ \\
\hline & $(0.005)$ & $(0.004)$ & $(0.003)$ & $(0.004)$ & $(0.007)$ \\
\hline \multirow[t]{2}{*}{ Age } & $0.026 * * *$ & $0.034 * * *$ & $0.046 * * *$ & $0.046 * * *$ & $0.035 * * *$ \\
\hline & $(0.001)$ & $(0.001)$ & $(0.001)$ & $(0.001)$ & $(0.001)$ \\
\hline \multirow[t]{2}{*}{ Age Squared } & $-0.000 * * *$ & $-0.000 * * *$ & $-0.000 * * *$ & $-0.000 * * *$ & $-0.000 * * *$ \\
\hline & $(0.000)$ & $(0.000)$ & $(0.000)$ & $(0.000)$ & $(0.000)$ \\
\hline \multirow[t]{2}{*}{ Union } & $0.092 * * *$ & $0.119 * * *$ & $0.142 * * *$ & $0.086 * * *$ & $-0.078 * * *$ \\
\hline & $(0.005)$ & $(0.005)$ & $(0.005)$ & $(0.006)$ & $(0.008)$ \\
\hline $\mathrm{N}$ & 1419475 & 1419475 & 1419475 & 1419475 & 1419475 \\
\hline R-Square & 0.087 & 0.176 & 0.243 & 0.231 & 0.155 \\
\hline
\end{tabular}

Note: The models also include year fixed-effects, industry fixed-effects, racial status, the interaction terms between four Census regions and metropolitan status, and the interaction terms between gender, marital, and parental status. Estimates are available upon request. 
Figure 1. Real Wage Trends and Inter-Percentile Wage Gaps, 1987-2014
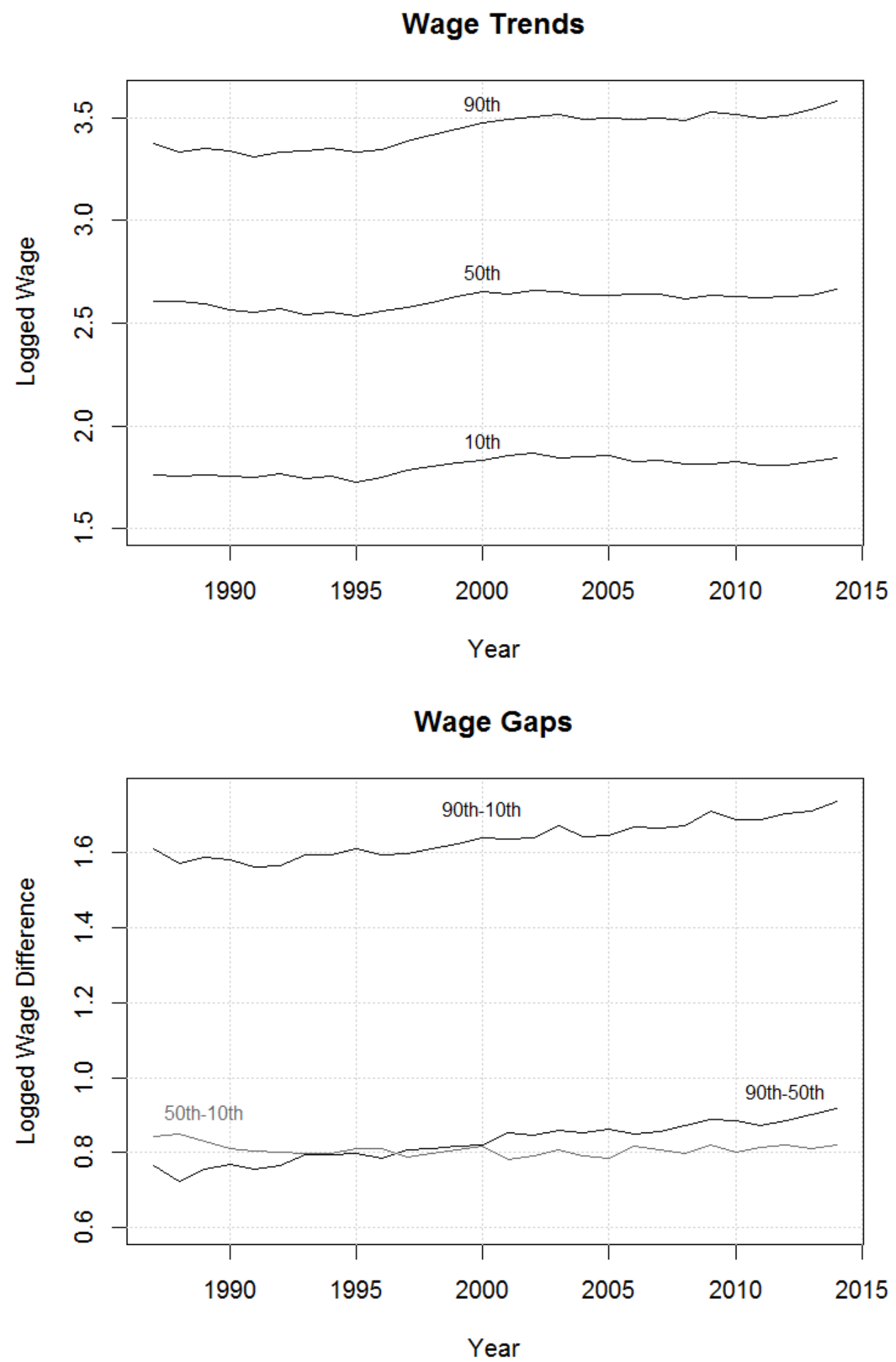
Figure 2. Distribution of Workers across Four Firm-Size Categories

\section{Distribution of Workers}

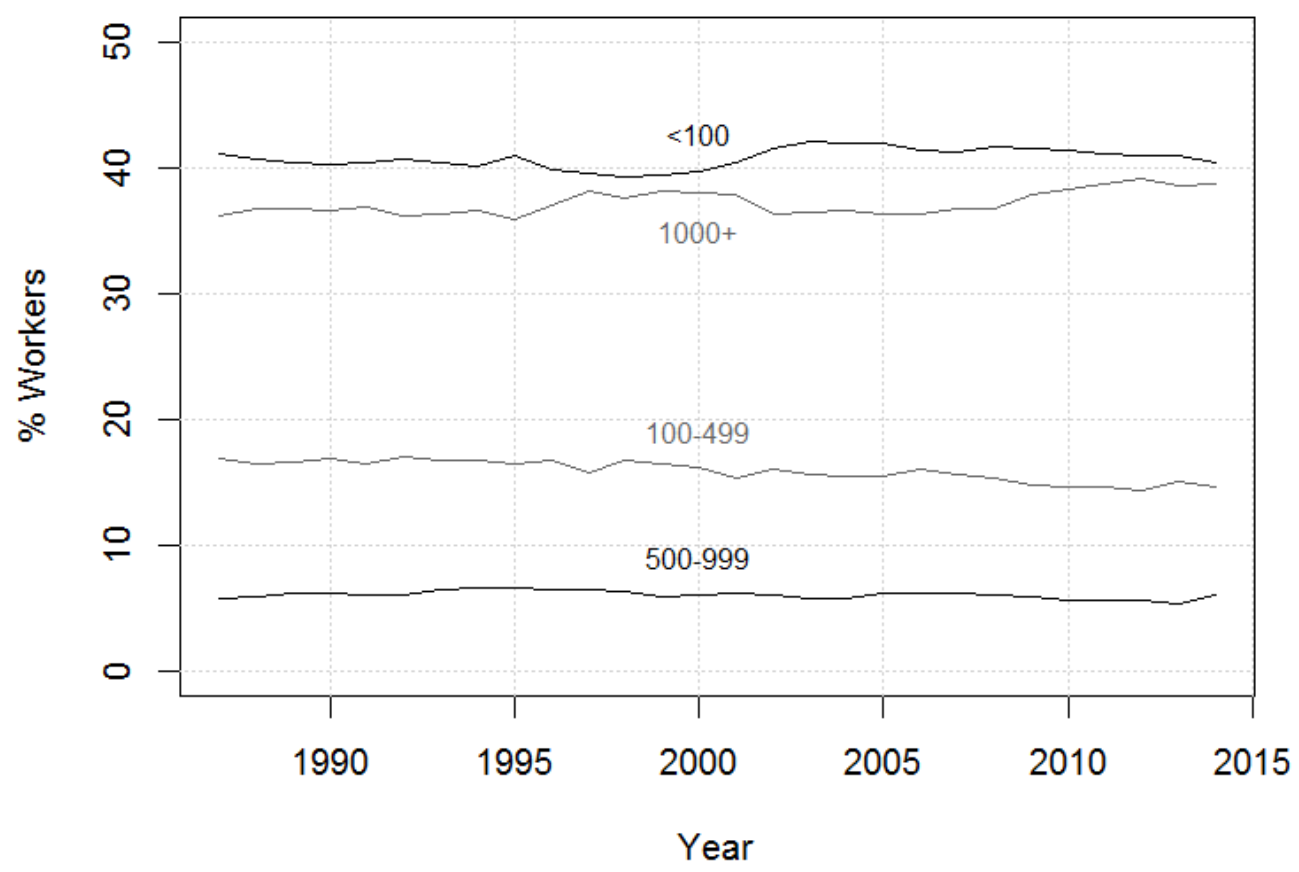

Changes from 1987

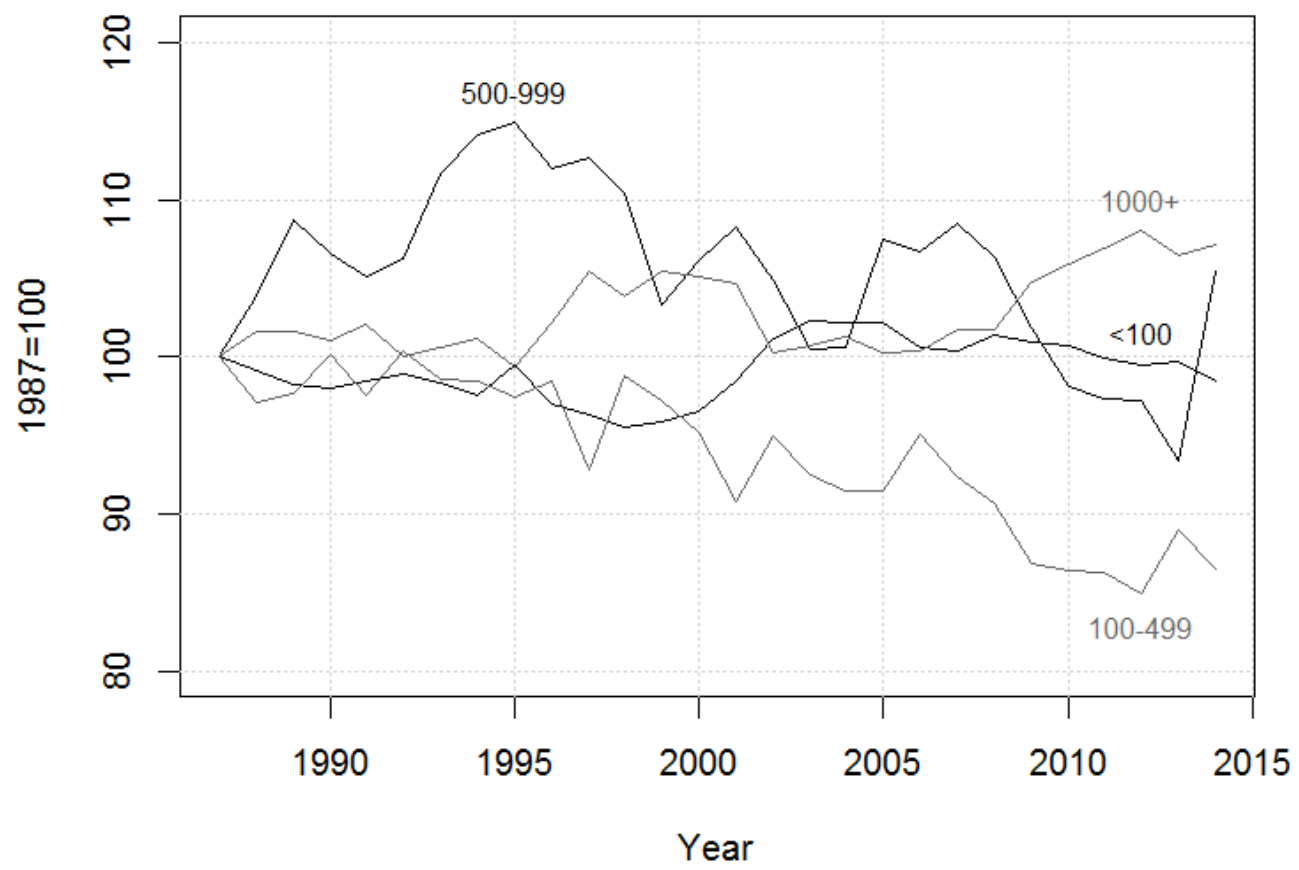


Figure 3. Quantile-Specific Treatments and Distributional Consequences
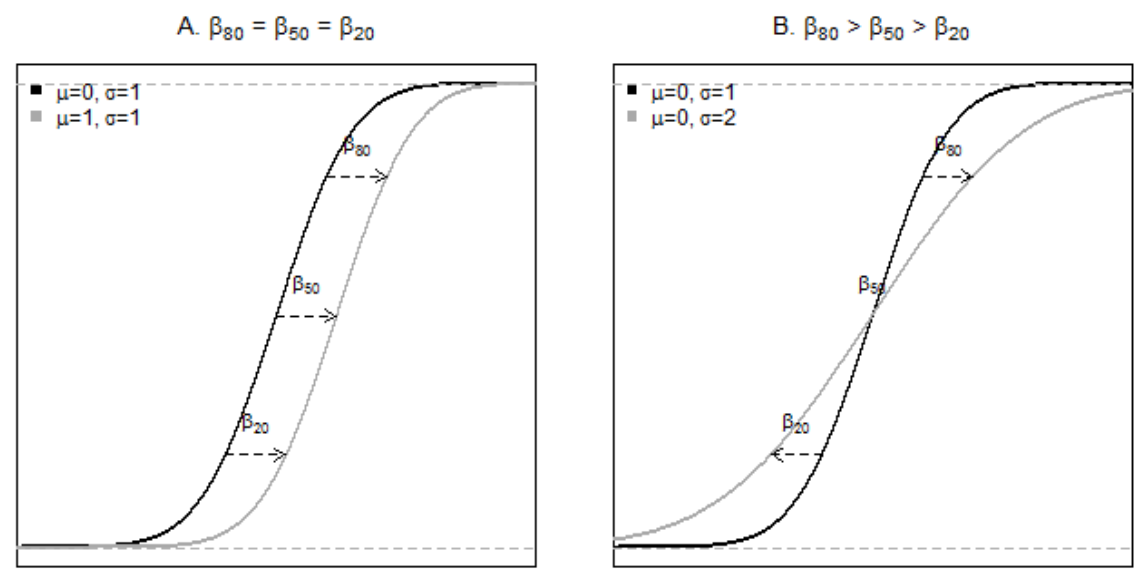

C. $\beta_{80}<\beta_{50}<\beta_{20}$

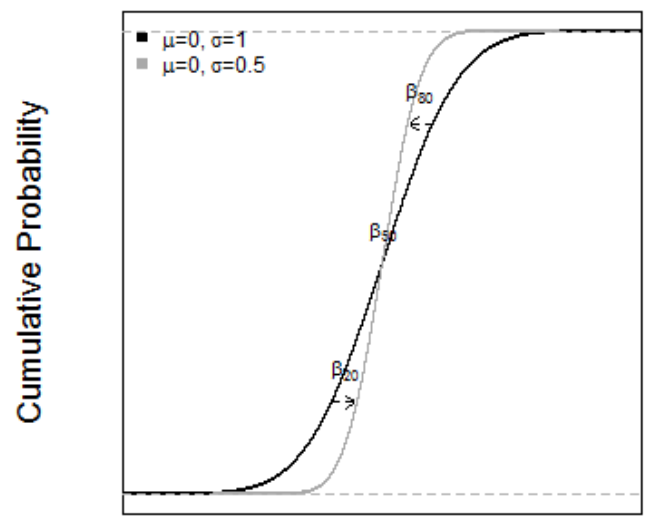

E. $\beta_{80}<\beta_{50}>\beta_{20}$

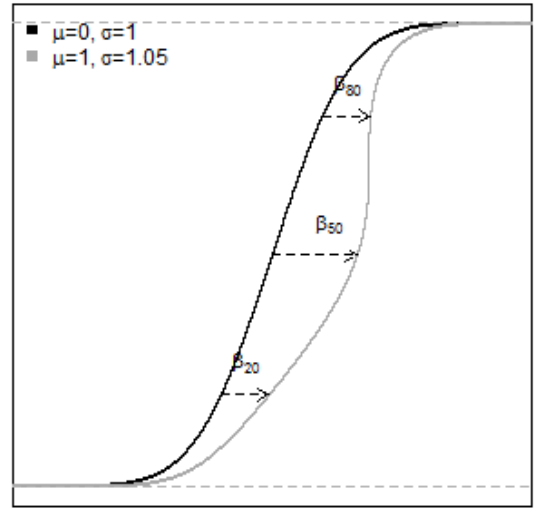

D. $\beta_{80}>\beta_{50}>\beta_{20}$

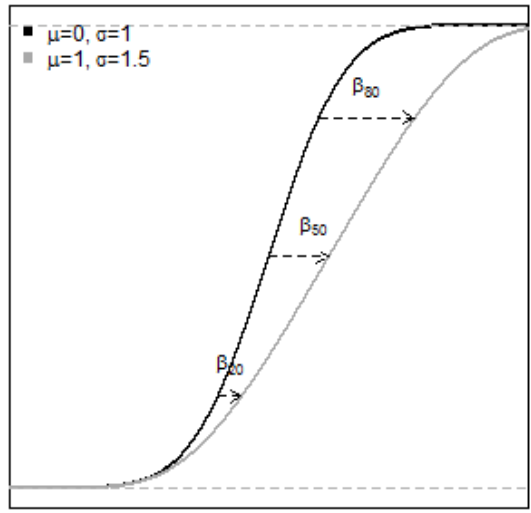

F. $\beta_{80}<\beta_{50}<\beta_{20}$

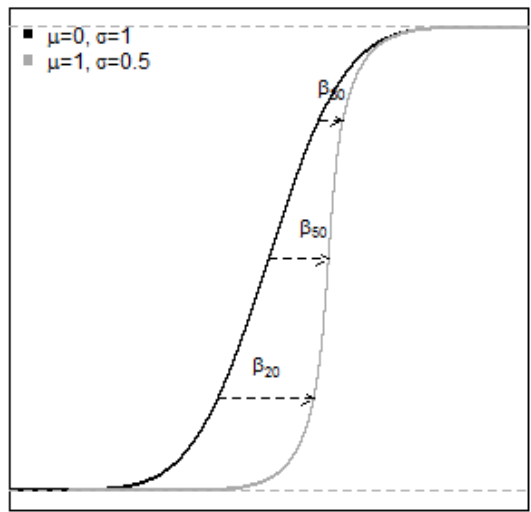

Outcome 
Figure 4. Logged Wage Difference from Firms with <100 Employees, 1987-2014
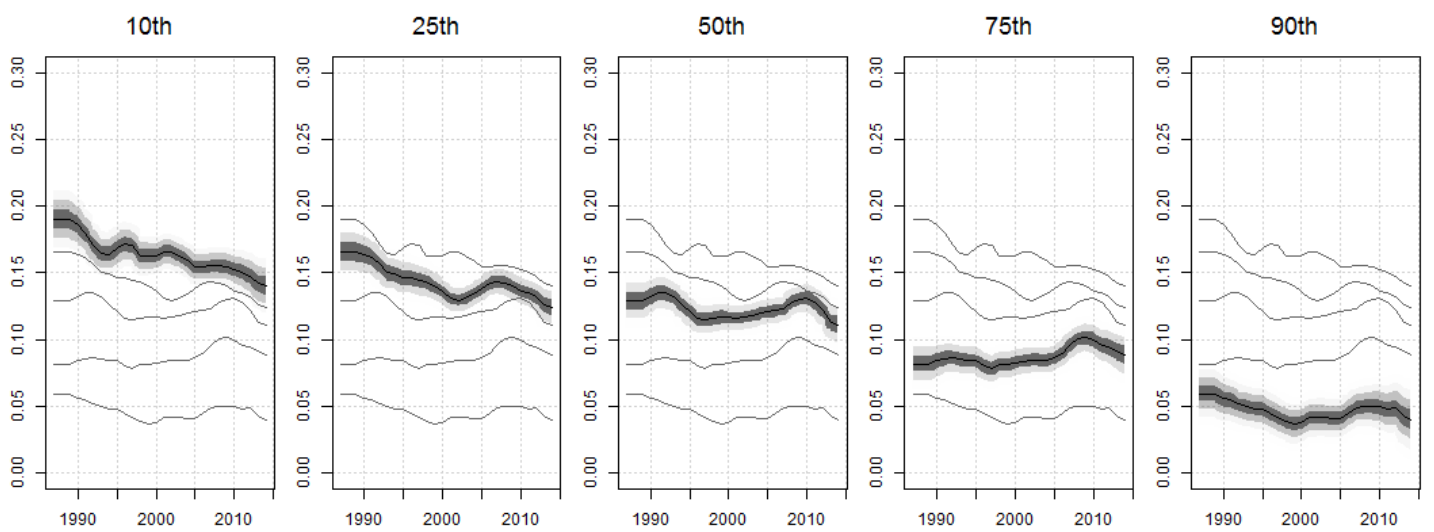

100-499
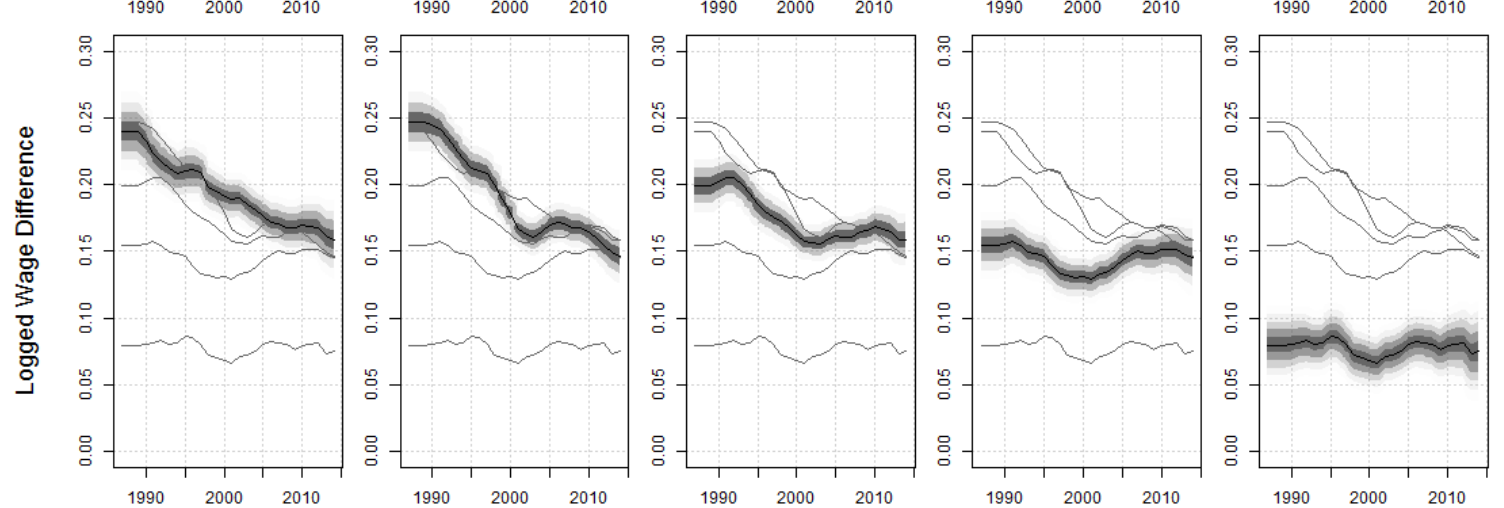

500-999
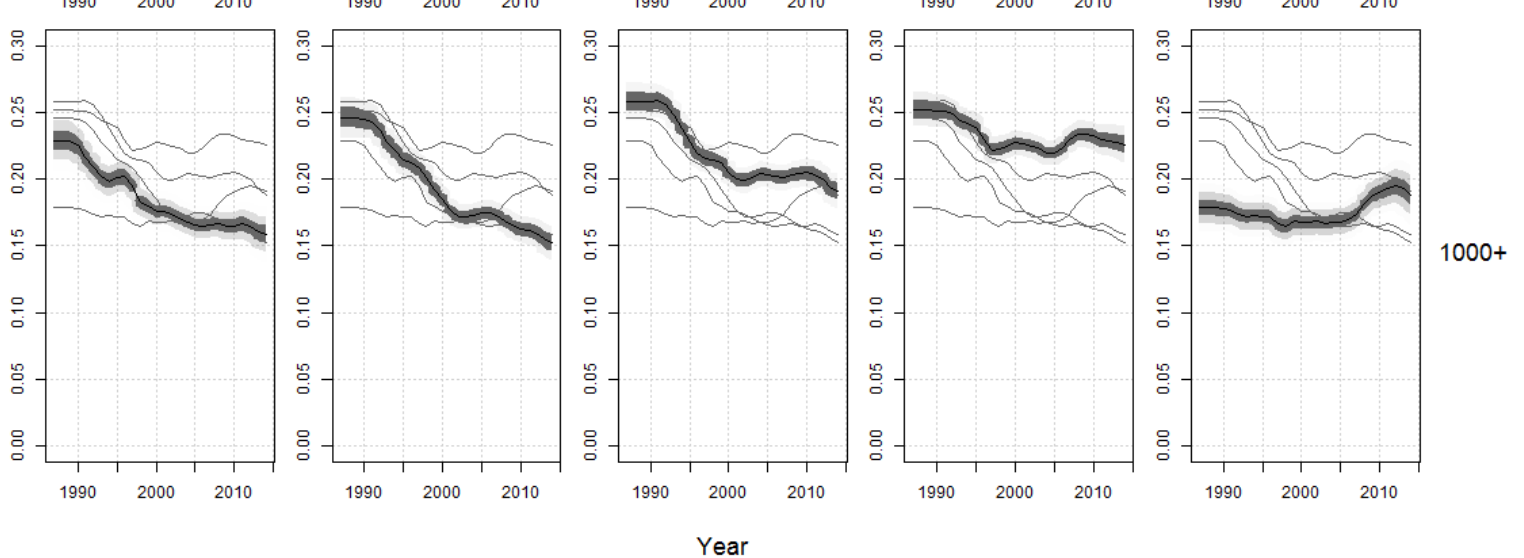
Figure 5. The Contribution of FSWE to Rising Wage Inequality

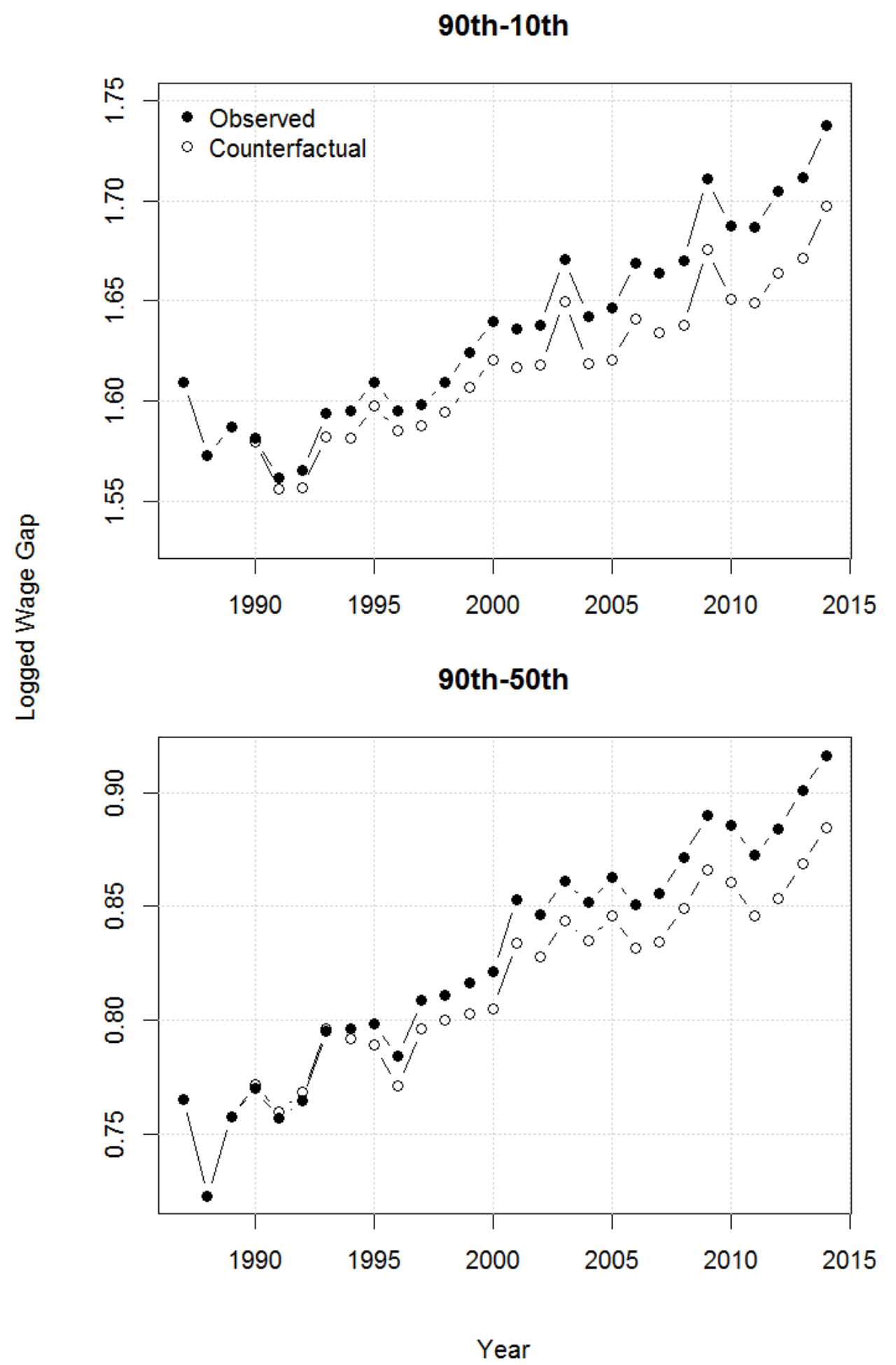




\begin{tabular}{|c|c|c|c|c|}
\hline & \multicolumn{4}{|c|}{ Firm Size } \\
\hline & $<100$ Workers & $100-499$ & $500-999$ & $1000+$ \\
\hline Logged Wage & 2.476 & 2.651 & 2.711 & 2.768 \\
\hline (S.D.) & 0.675 & 0.642 & 0.319 & 0.311 \\
\hline \multicolumn{5}{|l|}{ Human Capital } \\
\hline \multicolumn{5}{|l|}{ (Less than High School) } \\
\hline High School & 0.355 & 0.337 & 0.319 & 0.311 \\
\hline Some College & 0.262 & 0.269 & 0.278 & 0.287 \\
\hline College & 0.162 & 0.191 & 0.209 & 0.226 \\
\hline Advanced Degree & 0.065 & 0.085 & 0.098 & 0.102 \\
\hline Age & 41.264 & 41.576 & 41.621 & 41.611 \\
\hline (S.D.) & 10.845 & 10.702 & 10.604 & 10.671 \\
\hline Union & 0.011 & 0.024 & 0.027 & 0.031 \\
\hline \multicolumn{5}{|l|}{$\underline{\text { Racial Status }}$} \\
\hline \multicolumn{5}{|l|}{$\overline{\text { (White) }}$} \\
\hline Black & 0.088 & 0.112 & 0.124 & 0.123 \\
\hline Hispanic & 0.156 & 0.121 & 0.104 & 0.095 \\
\hline Asian & 0.042 & 0.042 & 0.044 & 0.048 \\
\hline Other & 0.013 & 0.013 & 0.012 & 0.013 \\
\hline \multicolumn{5}{|l|}{ Demographic } \\
\hline \multicolumn{5}{|l|}{ (Men/Married/OKid) } \\
\hline Men/Married/1Kid & 0.067 & 0.066 & 0.071 & 0.067 \\
\hline Men/Married/2Kids & 0.074 & 0.070 & 0.077 & 0.071 \\
\hline Men/Married/3+Kids & 0.039 & 0.036 & 0.038 & 0.035 \\
\hline Men/Single/OKid & 0.058 & 0.063 & 0.066 & 0.069 \\
\hline Men/Single/1Kid & 0.011 & 0.011 & 0.013 & 0.012 \\
\hline Men/Single/2Kids & 0.006 & 0.007 & 0.006 & 0.007 \\
\hline Men/Single/3+Kids & 0.004 & 0.004 & 0.004 & 0.004 \\
\hline Men/Other/OKid & 0.049 & 0.051 & 0.053 & 0.052 \\
\hline Men/Other/1Kid & 0.027 & 0.028 & 0.031 & 0.029 \\
\hline Men/Other/2Kids & 0.018 & 0.019 & 0.020 & 0.018 \\
\hline Men/Other/3+Kids & 0.009 & 0.010 & 0.009 & 0.009 \\
\hline Women/Married/OKid & 0.099 & 0.108 & 0.103 & 0.111 \\
\hline Women/Married/1Kid & 0.077 & 0.084 & 0.080 & 0.085 \\
\hline Women/Married/2Kids & 0.088 & 0.099 & 0.098 & 0.102 \\
\hline Women/Married/3+Kids & 0.056 & 0.058 & 0.053 & 0.055 \\
\hline Women/Single/OKid & 0.126 & 0.108 & 0.100 & 0.104 \\
\hline Women/Single/1Kid & 0.005 & 0.004 & 0.003 & 0.003 \\
\hline
\end{tabular}




\begin{tabular}{|c|c|c|c|c|}
\hline Women/Single/2Kids & 0.002 & 0.002 & 0.001 & 0.001 \\
\hline Women/Single/3+Kids & 0.001 & 0.001 & 0.001 & 0.001 \\
\hline Women/Other/OKid & 0.070 & 0.061 & 0.057 & 0.055 \\
\hline Women/Other/1Kid & 0.010 & 0.010 & 0.009 & 0.009 \\
\hline Women/Other/2Kids & 0.005 & 0.005 & 0.004 & 0.004 \\
\hline Women/Other/3+Kids & 0.002 & 0.002 & 0.002 & 0.001 \\
\hline \multicolumn{5}{|l|}{ Industry } \\
\hline \multicolumn{5}{|l|}{ (Natural Services) } \\
\hline Construction & 0.122 & 0.064 & 0.041 & 0.019 \\
\hline Manufacturing & 0.121 & 0.259 & 0.246 & 0.232 \\
\hline Transp. \& Utilities & 0.044 & 0.056 & 0.060 & 0.099 \\
\hline Wholesale \& Retail & 0.219 & 0.149 & 0.145 & 0.235 \\
\hline Service & 0.453 & 0.450 & 0.489 & 0.401 \\
\hline \multicolumn{5}{|l|}{ Location } \\
\hline \multicolumn{5}{|l|}{$\begin{array}{l}\text { Non-Metropolitan } \\
\text { (New England) }\end{array}$} \\
\hline Middle Atlantic & 0.012 & 0.015 & 0.015 & 0.010 \\
\hline East-North-Central & 0.032 & 0.041 & 0.037 & 0.028 \\
\hline West-North-Central & 0.025 & 0.025 & 0.020 & 0.016 \\
\hline South Atlantic & 0.031 & 0.031 & 0.032 & 0.026 \\
\hline East-South-Central & 0.021 & 0.025 & 0.024 & 0.018 \\
\hline West-South-Central & 0.020 & 0.015 & 0.014 & 0.014 \\
\hline Mountain & 0.014 & 0.009 & 0.009 & 0.008 \\
\hline Pacific & 0.011 & 0.009 & 0.008 & 0.006 \\
\hline \multicolumn{5}{|l|}{ Metropolitan } \\
\hline New England & 0.043 & 0.049 & 0.053 & 0.047 \\
\hline Middle Atlantic & 0.130 & 0.134 & 0.139 & 0.126 \\
\hline East-North-Central & 0.121 & 0.142 & 0.137 & 0.146 \\
\hline West-North-Central & 0.042 & 0.049 & 0.050 & 0.055 \\
\hline South Atlantic & 0.154 & 0.141 & 0.148 & 0.161 \\
\hline East-South-Central & 0.033 & 0.034 & 0.036 & 0.040 \\
\hline West-South-Central & 0.091 & 0.083 & 0.087 & 0.096 \\
\hline Mountain & 0.051 & 0.047 & 0.047 & 0.056 \\
\hline Pacific & 0.160 & 0.144 & 0.134 & 0.140 \\
\hline
\end{tabular}


Appendix B. Partial Coefficients and Robust Standard Errors Predicting Logged WAGE PerCeNTILES, SIPP 1996-2008

\begin{tabular}{|c|c|c|c|c|c|}
\hline & 10th & 25th & 50th & 75th & 90th \\
\hline \multicolumn{6}{|l|}{$\frac{\text { Firm Size }}{(<25 \text { Workers })}$} \\
\hline $25-99$ & $\begin{array}{l}0.152^{* * *} \\
(0.003)\end{array}$ & $\begin{array}{l}0.124^{* * *} \\
(0.002)\end{array}$ & $\begin{array}{l}0.110^{* * *} \\
(0.002)\end{array}$ & $\begin{array}{l}0.078^{* * *} \\
(0.002)\end{array}$ & $\begin{array}{l}0.042^{* * *} \\
(0.002)\end{array}$ \\
\hline $100+$ & $\begin{array}{l}0.186^{* * *} \\
(0.002)\end{array}$ & $\begin{array}{l}0.173 * * * \\
(0.002)\end{array}$ & $\begin{array}{l}0.179 * * * \\
(0.001)\end{array}$ & $\begin{array}{l}0.169 * * * \\
(0.002)\end{array}$ & $\begin{array}{l}0.134^{* * *} \\
(0.002)\end{array}$ \\
\hline \multicolumn{6}{|l|}{ Human Capital } \\
\hline High School & $\begin{array}{l}0.276^{* * *} \\
(0.003)\end{array}$ & $\begin{array}{l}0.290^{* * *} \\
(0.002)\end{array}$ & $\begin{array}{l}0.209^{* * *} \\
(0.002)\end{array}$ & $\begin{array}{l}0.120^{* * *} \\
(0.002)\end{array}$ & $\begin{array}{l}0.062 * * * \\
(0.002)\end{array}$ \\
\hline Some College & $\begin{array}{l}0.408^{* * *} \\
(0.003)\end{array}$ & $\begin{array}{l}0.465^{* * *} \\
(0.002)\end{array}$ & $\begin{array}{l}0.414^{* * *} \\
(0.002)\end{array}$ & $\begin{array}{l}0.303^{* * *} \\
(0.002)\end{array}$ & $\begin{array}{l}0.180^{* * *} \\
(0.002)\end{array}$ \\
\hline College & $\begin{array}{l}0.527^{* * *} \\
(0.003)\end{array}$ & $\begin{array}{l}0.656^{* * *} \\
(0.002)\end{array}$ & $\begin{array}{l}0.738^{* * *} \\
(0.002)\end{array}$ & $\begin{array}{l}0.764^{* * *} \\
(0.002)\end{array}$ & $\begin{array}{l}0.691^{* * *} \\
(0.003)\end{array}$ \\
\hline Advanced Degree & $\begin{array}{l}0.543^{* * *} \\
(0.004)\end{array}$ & $\begin{array}{l}0.699 * * * \\
(0.003)\end{array}$ & $\begin{array}{l}0.861^{* * *} \\
(0.002)\end{array}$ & $\begin{array}{l}1.060^{* * *} \\
(0.003)\end{array}$ & $\begin{array}{l}1.236 * * * \\
(0.005)\end{array}$ \\
\hline Age & $\begin{array}{l}0.023^{* * *} \\
(0.001)\end{array}$ & $\begin{array}{l}0.030^{* * *} \\
(0.000)\end{array}$ & $\begin{array}{l}0.045^{* * *} \\
(0.000)\end{array}$ & $\begin{array}{l}0.058^{* * *} \\
(0.000)\end{array}$ & $\begin{array}{l}0.056^{* * *} \\
(0.001)\end{array}$ \\
\hline Age Squared & $\begin{array}{l}-0.000^{* * *} \\
(0.000)\end{array}$ & $\begin{array}{l}-0.000^{* * *} \\
(0.000)\end{array}$ & $\begin{array}{l}-0.001^{* * *} \\
(0.000)\end{array}$ & $\begin{array}{l}-0.001^{* * *} \\
(0.000)\end{array}$ & $\begin{array}{l}-0.001^{* * *} \\
(0.000)\end{array}$ \\
\hline Union & $\begin{array}{l}0.071^{* * *} \\
(0.002)\end{array}$ & $\begin{array}{l}0.115^{* * *} \\
(0.002)\end{array}$ & $\begin{array}{l}0.156^{* * *} \\
(0.002)\end{array}$ & $\begin{array}{l}0.083^{* * *} \\
(0.002)\end{array}$ & $\begin{array}{l}-0.077^{* * *} \\
(0.003)\end{array}$ \\
\hline Tenure & $\begin{array}{l}0.032^{* * *} \\
(0.000)\end{array}$ & $\begin{array}{l}0.035^{* * *} \\
(0.000)\end{array}$ & $\begin{array}{l}0.030^{* * *} \\
(0.000)\end{array}$ & $\begin{array}{l}0.020^{* * *} \\
(0.000)\end{array}$ & $\begin{array}{l}0.012 * * * \\
(0.000)\end{array}$ \\
\hline Tenure Squared & $\begin{array}{l}-0.001^{* * *} \\
(0.000)\end{array}$ & $\begin{array}{l}-0.001^{* * *} \\
(0.000)\end{array}$ & $\begin{array}{l}-0.000^{* * *} \\
(0.000)\end{array}$ & $\begin{array}{l}-0.000^{* * *} \\
(0.000)\end{array}$ & $\begin{array}{l}-0.000^{* * *} \\
(0.000)\end{array}$ \\
\hline $\mathrm{N}$ & 1419475 & 1419475 & 1419475 & 1419475 & 1419475 \\
\hline R-Square & 0.087 & 0.176 & 0.243 & 0.231 & 0.155 \\
\hline
\end{tabular}

Note: The models also include year fixed-effects, industry fixed-effects, racial status, the interaction terms between four Census regions and metropolitan status, and the interaction terms between gender, marital, and parental status. Estimates are available upon request. 
APPENDix C. LOGGED WAGE DifFERENCE FROM FiRMS WITH <25 EMPLOYEES, SIPP, 19962008


25-99
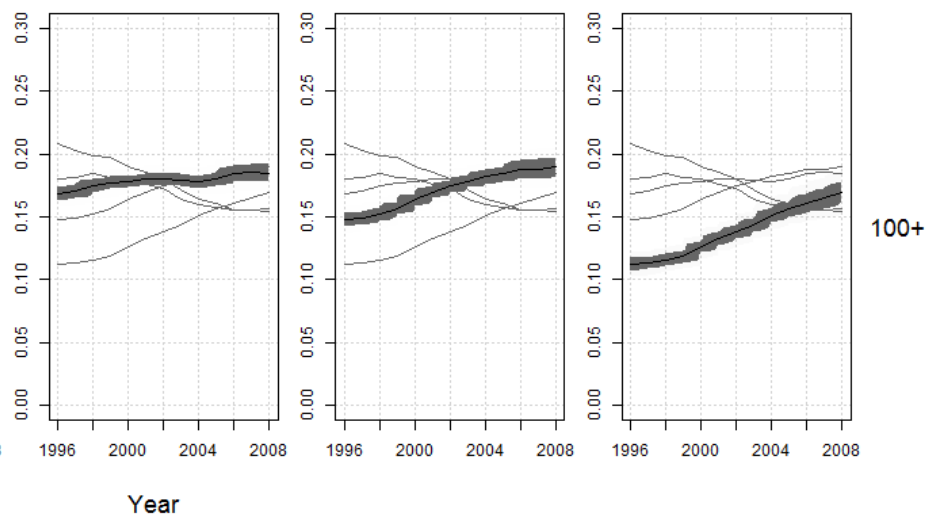